Oḷegs Barānovs, Jānis Salmiņš, Irina Skribāne

\title{
Latvijas produktivitātes attīstības tendences, izaicinājumi un iespējas
}

Ar produktivitāti parasti saprot attiecību starp ražošanas faktoru (darbs, kapitāls u. c.) ieguldījumu un izlaidi uzṇēmumā, nozarē vai tautsaimniecībā kopumā. Palielināt produktivitāti nozīmē efektīvāk izmantot esošos resursus jeb palielināt ražošanas efektivitāti un konkurētspēju un tādējādi veicināt augstākus dzīves standartus.

Produktivitāte tiek uzskatīta par galveno ekonomiskās izaugsmes un konkurētspējas avotu, un tā tiek plaši izmantota starptautiskos salīdzinājumos un valstu darbības novērtējumā. Nobela prēmijas laureāts Pauls Krugmans ir teicis: "Produktivitāte vēl nav viss, bet ilgtermiņā tā ir gandrīz viss. Valsts spēja uzlabot dzìves līmeni laika gaitā ir gandrīz pilnībā atkarīga no tās spējas palielināt savu ražošanu uz vienu strādnieku."

Lai politikas veidotāji varētu noteikt prioritātes, rīkoties un gūt redzamus makroekonomiskos ieguvumus, ir nepieciešama skaidra izpratne par produktivitātes palielināšanas iespējām un esošajiem šḳēršliem.

Autori sniedz ieskatu literatūrā, analizē produktivitātes dinamiku Latvijā, tostarp Covid-19 pandēmijas ietekmi uz produktivitāti, novērtē tehnolog̣iskās intensitātes strukturālās izmaiṇas, kā arī ar produktivitāti saistītos faktorus (inovācijas, digitalizācija, cilvēkkapitāls u. c.), kā arī pamato attīstības scenārijus un formulē secinājumus.

Problemātikas analīzei izmantoti publiski pieejami Centrālās statistikas pārvaldes, Eiropas Savienības Statistikas biroja, Ekonomiskās

1 Krugman, P. R. (1994). The age of diminished expectations: U.S. economic policy in the 1990s (Rev. and updated ed.). Cambridge, Mass: MIT Press. 
sadarbības un attīstîbas organizācijas u. c. statistikas dati. Lai noteiktu darbaspēka resursu pārdales ietekmi uz kopējo produktivitātes dinamiku Latvijas ekonomikā, tika izmantota strukturālo izmainu ietekmes analīzes (shift share analysis) metode. Tautsaimniecības attīstības prognožu izstrādei izmantots autoru izstrādāts un Latvijas ekonomikai pielāgots Hermin vidēja termiņa modelis.

\section{Latvijas produktivitātes pētijumu analīze}

Produktivitāte pasaules zinātniskā literatūrā ir loti plaši pētìta. Izdotas daudzas monogrāfijas, publicēti raksti zinātniski pētnieciskos krājumos utt. Produktivitāti pēta un meklē risinājumus tās veicināšanai arī starptautiskās organizācijas - Ekonomiskās sadarbības un attīstības organizācija (ESAO), Starptautiskais Valūtas fonds (SVF), Eiropas Komisija (EK) un citas.

Īpaši produktivitātes tematika ir kḷuvusi aktuāla pēdējās desmitgadēs, kad vērojama produktivitātes izaugsmes pazemināšanās pasaulē, sevišķi attīstītajās valstīs. ESAO norāda uz daudziem faktoriem, kas kavē produktivitātes pieaugumu, tostarp demogrāfiju, izglìtību, nevienlīdzību, globalizāciju, vidi un parādu. Būtiski produktivitātes attīstîbas tempu ietekmē arī zināšanās balstītas kapitāla uzkrāšanas un uzṇēmējdarbības uzsākšanas pieauguma samazināšanās. Vislielākā problēma, secinājusi ESAO, ir tempa palēnināšanās, kādā inovācija izplatās ekonomikā. ${ }^{2}$

Arvien vairāk tiek atzìts, ka produktivitāti veicinoša politika var būt īpaši grūts uzdevums. Šādu uzdevumu vēl vairāk apgrūtina fakts, ka, runājot par produktivitāti, nav ne "sudraba ložu" risinājuma, ne standarta reformu kopuma, ko jebkurā valstī var īstenot vienādi. ${ }^{3}$

Lai panāktu pamatotu politikas lēmumu veidošanu, kas balstīti uz neatkarīgu analīzi un ieteikumiem, vairākās ESAO valstīs ir izveidotas speciālās institūcijas - Produktivitātes padomes, kuras darbojas kā uzraudzības un padomdevēju struktūrvienības ekonomiskās politikas, strukturālo reformu un regulējuma jomā. ESAO 2015. gadā izveidoja Globālo produktivitātes forumu (GFP), kura mērḳis ir veicināt starptautisko sadarbību starp Produktivitātes padomēm. Arī ES, līdzīga kā ESAO GFP, ir izveidota produktivitātes analīzes dialoga platforma.

Latvijā izpratne par produktivitātes lomu izaugsmē un labklājības nodrošināšanā pieaug. Latvijas produktivitātes tendenču monitorings un politikas jautājumi produktivitātes veicināšanai ir iekḷauti vairākos politikas plānošanas

OECD. (2015). The Future of Productivity, OECD Publishing, Paris.

Renda, A., Dougherty, S. (2017). Pro-Productivity Institutions: Learning from National Experience, OECD Productivity Working Papers, Paris, 2017-07, p. 197. 
dokumentos, piemēram, Latvijas Nacionālajā reformu programmā stratēgijas "Eiropa 2020" ieviešanai, Nacionālajā attīstības plānā, Latvijas viedās specializācijas stratēgijā, Latvijas nacionālajā industriālajā politikā un citos.

2020. gada 2. jūlijā Saeimā apstiprinātajā Latvijas Nacionālajā attīstîbas plānā 2021.-2027. gadam kā viens no prioritārajiem virzieniem ir noteikts "Produktivitāte, inovācija un eksports". Nacionālajā attīstības plānā ir norādīts, ka "turpmākā tautsaimniecības izaugsme un augstāka dzìves līmeņa nodrošināšana Latvijas iedzīvotājiem ir atkarīga no spējas strauji mainīgajā vidē veidot jaunas, zināšanās balstītas konkurētspējas priekšrocības, proti, kāpināt produktivitāti caur ieguldījumiem cilvēkkapitālā, pētniecībā un inovācijā, kā arī jaunu, digitālu tehnoloǵiju ieviešanā". ${ }^{4}$

Latvijā līdzīgi kā citās valstīs tiek veikti pētījumi par produktivitāti un konkurētspēju, kā arī ar produktivitāti cieši saistīto faktoru - investīcijas, inovācijas, digitālās tehnologijas, nodarbinātība u. tml. - izpēte.

Pētỉjumus par Latvijas produktivitāti var iedalìt 2 grupās:

- starptautisko organizāciju pètījumi;

- Latvijas zinātnieku un pētnieku, kā arī valsts institūciju pētījumi.

Pētijumus par produktivitāti Latvijā veic starptautisko organizāciju - ESAO, SVF, Eiropas Komisija u. c. - institūcijas. Latvija ir arī iekḷauta dažādos starptautiskajos reitingos, kas vērtē valstu konkurētspēju un ar produktivitāti saistītos faktorus.

ESAO reizi divos gados izstrādā "Ekonomikas pārskatu par Latviju", kurā tiek izvērtēta ekonomiskā situācija, galveno reformu īstenošanas process, tautsaimniecības izaicinājumi un sniegtas rekomendācijas. Šajos pārskatos ESAO eksperti analizē arī produktivitātes attīstîbu.

2019. gada ESAO "Ekonomikas pārskatā par Latviju” eksperti norādīja, ka Latvijai ir nepieciešama spēcīgāka produktivitātes izaugsme, lai uzlabotu dzives kvalitāti. ESAO uzskata, ka galvenie izaicinājumi produktivitātes palielināšanai Latvijā ir saistīti ar salīdzinoši augstu ienākumu nevienlīdzību, no vienas puses, un zemu inovācijas līmeni, no otras puses. Produktivitātes pieauguma tempi samazinājās pēc 2008. gada, jo finanšu krīze pasliktināja kredītu pieejamību, kavējot kapitāla padziḷināšanos un ieguldījumus inovācijās. Prasmju, īpaši digitālo tehnolog̣iju apgūšanai nepieciešamo prasmju, trūkums, vājā konkurence dažās

4 Pārresoru koordinācijas centrs. (2020). Latvijas Nacionālais attīstības plāns 2021.-2027. gadam. Rìga, 44. lpp. Pieejams: https://www.pkc.gov.lv/sites/default/files/inline-files/NAP2027_apstiprin\%C4\%81ts\%20Saeim\%C4\%81_1.pdf 
nozarēs ar nozìmīgu valsts un pašvaldības uzṇēmumu līdzdalību arī bremzē produktivitātes pieaugumu. ${ }^{5}$

Arī Starptautiskā Valūtas fonda pārskatos par Latviju bieži tiek skarta produktivitātes tematika. 2019. gada SVF ziņojumā par Latviju tika norādīts, ka produktivitāti kavē šķēršlı i investīcijām un jaunu tehnologiiju zemā izplatība. Kopš krīzes kopējā faktoru produktivitāte (TFP) ir nepārtraukti pieaugusi, bet vidēji tā joprojām ir krietni zem augstā pirmskrīzes līmeņa. Galvenais iemesls ir l’oti lēnā cilvēku un fiziskā kapitāla transformācija. Latvijas kapitālu veido galvenokārt ēkas un būves. Kamēr intelektuālā īpašuma aktīvi ir tikai 1,2\% no Latvijas nefinanšu aktīvu kopējās neto vērtỉbas, kas ir viens no zemākiem rādītājs ES dalïbvalstīs.

Pētniecības un attīstîbas tērinin - 0,5\% no IKP - ir tikai ceturtā daḷa no ES vidējā līmeņa. Arī novatorisko uzṇēmumu īpatsvars - tikai 6,3\% no kopējā skaita - ir ḷoti zems salīdzinājumā ar vidējo rādītāju ES, kur tas ir $14 \% .{ }^{6}$

Regulāri ekonomikas attīstību, tostarp produktivitāti, analizē Eiropas Komisija, gan vērtējot un salīdzinot ES valstis savā starpā, gan padziḷināti vērtējot konkrētas ES dalībvalstīs. Eiropas Komisija 2020. gada "Dienestu darba dokumentā”, līdzīgi kā 2019. gada dokumentā, atkārtoti norādīja, ka produktivitātes pieauguma tempa samazināšanās liecina par to, ka agrīnā iedzīšanas posma sniegtie vieglie ieguvumi ir izsmelti. Darbaspēka prasmju trūkums un neatbilstība ir viens no galvenajiem šķēršliem uzṇēmēju investīcijām un ierobežo ražìguma pieaugumu. ${ }^{7}$

Latvijas konkurētspēju un ar produktivitāti saistīto faktoru attīstību starptautiskā kontekstā raksturo dažādu organizāciju veidotie reitingi. Globālās konkurētspējas indeksa (GCI) reitings, ko ik gadu publicē Pasaules Ekonomikas forums (WEF), ir pasaulē vispāratzìts valstu konkurētspējas novērtēšanas rīks. Neraugoties uz dažādām metodologiskām nepilnībām, GCI reitings sniedz vērtīgu informāciju politikas veidotājiem un ḷauj noteikt tās jomas, kurās attiecīgajai valstij ir atpalicība no citām valstīm. WEF publicētajā reitingā Latvija 2019. gadā ieñēma 41. vietu starp 141 pasaules valsti. ${ }^{8}$ Kopumā no GCI reitinga var secināt, ka Latvijas ekonomikas ilgtspējīgas izaugsmes problēmas ir jārisina kompleksi ar

OECD. (2019). OECD Economic Surveys: Latvia 2019, OECD Publishing, Paris. Pieejams: https:/doi. org/10.1787/f8c2f493-en

6 International Monetary Fund. Republic of Latvia: 2019 Article IV Consultation-Press Release; and Staff Report. August 7, 2019. Pieejams: https://www.imf.org/en/Publications/CR/Issues/2019/08/06/ Republic-of-Latvia-2019-Article-IV-Consultation-Press-Release-and-Staff-Report-48565

7 Eiropas Komisija. (2020). Komisijas dienestu darba dokuments. Ziņojums par Latviju - 2020. gads. Brisele, 26.02.2020. SWD (2020) 513 final, 4. lpp. Pieejams: https://ec.europa.eu/info/sites/info/files/ 2020-european_semester_country-report-latvia_lv.pdf

8 World Economic Forum. (2019). The Global Competitiveness Report. Geneva. Pieejams: http://www3. weforum.org/docs/WEF_TheGlobalCompetitivenessReport2019.pdf 
konkurētspējas palielināšanas problēmām, kas savukārt nav iespējams bez esošā ekonomikas modeḷa maiņas. Jauna uz zināšanām un inovācijām balstītā ekonomikas model̦a veidošanā īpaša uzmanība ir jāpievērš esošajām problēmām - institucionālās vides kvalitātei, uzṇēmējdarbības dinamisma palielināšanai, inovācijas spējas stiprināšanai.

Latvijas zinātnieki un pētnieki gan pēc savas iniciatīvas, gan pēc valdības institūciju pasūtỉjuma arvien biežāk pēta produktivitāti. Arī valsts institūcijas, piemēram, Latvijas Banka un Ekonomikas ministrija, savās publikācijās analizē produktivitāti.

Viens no jaunākajiem pētījumiem par produktivitātes attīstîbu Latvijā ir 2019. gada maijā publicētā monogrāfija "Produktivitātes celšana: tendences un nākotnes izaicinājumi” (zinātniskā redaktore - Inna Šteinbuka). Monogrāfija ir pirmais Latvijas Universitātes domnīcas LV PEAK zinātniskās darbības rezultāts. Tajā apkopota izpēte par produktivitātes un konkurētspējas faktoriem attīstītās valstīs, Eiropas Savienībā un Latvijā. Monogrāfijas autori secina, ka produktivitātes dinamiku ietekmē vairāki faktori, kuru apzināšana un izpēte ir svarīga ne tikai pētniekiem un uzṇēmējiem, tas ir svarīgs jautājums arī valsts politikas veidotājiem. Nesaprotot faktorus, kas nosaka produktivitātes dinamiku, nav iespējams piemērot atbilstošus politikas instrumentus, lai nodrošinātu noturīgu un ilgtspējīgu ekonomisko izaugsmi. Turklāt katrs produktivitāti ietekmējošo faktoru uzlabošanas pasākums ir jāvērtē kopējās ekonomiskās sistēmas kontekstā, kur viena elementa izmaiņas nenoliedzami prasa arī citu elementu kvalitatīvas un kvantitatīvas izmaiņas. Valsts izcilība kādā vienā konkurētspējas faktorā nevar kompensēt tās vājumu citās jomās?.

Latvijas Bankas eksperta Konstantīna Beņkovska pētijumā par resursu izlietojuma efektivitāti Latvijā ${ }^{10}$ analizēti produktivitātes palielināšanas strukturālie aspekti. Pētijumā norādīts, ka Latvijas produktivitātes zemāks līmenis nekā vidēji ES ir skaidrojams galvenokārt ar zemo kopējo faktoru produktivitāti, būtiskām atškịirīām ražošanas resursu (cilvēkkapitāla un kapitāla) kvalitātē. Pētījumā secināts, ka resursu sadalījums starp Latvijas uzņēmumiem ir tālu no efektīva, un tas nozīmē, ka, nemainot katra atsevišķa uzṇēmuma produktivitātes līmeni, nozīmīgi palielināt IKP varam, tikai pārvietojot darbaspēku vai kapitālu starp uzñēmumiem.

Šteinbuka, I. (zin. red.). (2019). Produktivitātes celšana: tendences un nākotnes izaicinājumi. Rīga: LU Akadēmiskais apgāds. Pieejams: https://www.apgads.lu.lv/fileadmin/user_upload/lu_portal/apgads/ PDF/Monografijas/Produktivitates_celsana/Produktivitate.pdf

10 Benkovskis, K. (2015). Misallocation of resources in Latvia: did anything change during the crisis? Latvijas Banka, Working Paper, No. 5. Pieejams: https://www.macroeconomics.lv/sites/default/files/wp_ 5_2015-en.pdf 
Arī Ekonomikas ministrija savos pārskatos regulāri analizē produktivitāti. 2019. gada Latvijas ekonomikas attīstības pārskatā Ekonomikas ministrija secina, ka Latvijas ekonomikas izaugsmi balsta produktivitātes kāpums. Latvijas rūpniecības produktivitātes līmeņa palielināšanas iespējas ir saistītas galvenokārt ar tās spēju veikt tehnologisko modernizāciju un inovācijas, paplašināt dalību pasaules vērtības ķēdēs, paaugstināt darbaspēka kvalifikāciju un uzlabot darbaspēka iekšējo mobilitāti valstî. Būtiska nozīme ir arī apstrādes rūpniecības un Latvijas tautsaimniecības kopumā strukturālai transformācijai uz augstākās pievienotās vērtības un augstākas produktivitātes aktivitātēm. ${ }^{11}$

No literatūras apskata par Latvijas produktivitāti var izdarīt vairākus secinājumus.

Pirmkārt, produktivitātes atšḳirība (plaisa) starp Latviju un attīstītajām valstīm, lai arī pēdējās desmitgadēs ir samazinājusies, tomēr joprojām ir liela. Latvijas produktivitātes atpalicība ir skaidrojama galvenokārt ar zemo kopējo faktoru produktivitāti, būtiskām atšķiīibām ražošanas resursu (cilvēku un kapitāla) kvalitātē.

Otrkārt, produktivitātes pieauguma temps Latvijā pēc 2008. gada finanšu krīzes ir samazinājies, ir pasliktinājusies kredītu pieejamība, kavējot kapitāla padziḷināšanos un ieguldījumus inovācijās. Produktivitātes dinamikas saglabāšana nebūs vienkārša, jo faktori, kas nodrošināja relatīvi augstus produktivitātes tempus iepriekšējos periodos, visticamāk, jau ir izsmelti, un uzṇēmumi tuvojas esošo tehnologiju iespēju robežām. Produktivitātes līmenis gandrīz visās nozarēs veido aptuveni trešdaļu no ES-15 videjjā rādìtāja. Lai samazinātu produktivitātes plaisu, būs nepieciešams nepārtraukts progress strukturālo reformu īstenošanā.

Treškārt, produktivitātes un konkurētspējas paaugstināšanai ir nepieciešama vispusīga un plašāka pieeja - spēcīgs sniegums vienā jomā nevar kompensēt vāju veikumu citā. Produktivitātes dinamiku ietekmē vairāki faktori, kuru apzināšana un izpēte ir svarīga ne tikai pētniekiem un uzṇēmējiem, tas ir svarīgs jautājums arī valsts politikas veidotājiem. Nesaprotot faktorus, kas nosaka produktivitātes dinamiku, nav iespējams piemērot atbilstošus politikas instrumentus, lai nodrošinātu noturīgu un ilgtspējīgu ekonomisko izaugsmi. Katrs produktivitāti ietekmējošo faktoru uzlabošanas pasākums ir jāvērtē kopējās ekonomiskās sistēmas kontekstā, kur viena elementa izmaiņas nenoliedzami prasa arī citu elementu kvalitatīvas un kvantitatīvas izmainas.

Ceturtkārt, produktivitātes pieaugumam arvien vairāk būs jābalstās uz zinātnesietilpīgām darbībām. Latvijas vājākais punkts ir bijušas inovācijas, kam

11 Latvijas Republikas Ekonomikas ministrija. (2019). Latvijas ekonomikas attīstības pārskats. Rīga, 80.81.lpp. Pieejams: https://em.gov.lv/files/tautsaimniecibas_attistiba/leap/leap2019_3.pdf 
nepieciešami ieguldījumi pētniecỉbā un izstrādē, cilvēku zināšanu un prasmju pilnveidošanā un citos nemateriālos aktīvos. Tomēr politikas veidotāji nedrīkst aizmirst "vecās" problēmas, piemēram, vājas institūcijas, infrastruktūras nepilnības, reǵionu nevienlīdzība u. c. Turklāt iedzīvotāju skaita samazināšanās rada papildu problēmu produktivitātes pieaugumam. Tā, piemēram, lietotāju skaita samazināšanās rada spriedzi attiecībā uz infrastruktūras efektivitāti un citām darbībām, kas nodrošina tikai vietējo tirgu.

Piektkārt, raugoties nākotnē un ņemot vērā Latvijas nelielo iekšzemes tirgu, Latvijas produktivitātes pieauguma izredzes ir cieši saistìtas ar tās panākumiem eksporta jomā. Latvijas zemo produktivitātes līmeni nosaka ražotāju salīdzinoši vājā līdzdalība globālajās vērtību ķēdēs un eksportētāju uzṇēmumu specializēšanās zemā tehnologiskā līmeņa ražošanā. Tāpēc Latvijas uzṇēmumu produktivitātes līmeṇa palielināšanas iespējas ir saistītas galvenokārt ar tās spēju veikt tehnologiisko modernizāciju un inovācijas, paplašināt dalību pasaules vērtības ķēdēs.

Sestkārt, ir nepieciešams nepārtraukts produktivitātes novērtēšanas un uzraudzības process, lai spētu laikus atklāt konkurētspējas riskus un iespējas, pielāgojoties mūsdienu strauji mainīgajai videi ar augstu nenoteiktības pakāpi. Jābūt politiskai gribai, lai šādu procesu izveidotu un uzturētu, šim nolūkam piešķirot atbilstošu un stabilu finansējumu. Produktivitātes un konkurētspējas novērtēšana un uzraudzība jāveic neatkarīgai institūcijai ārpus valdības. Vienlaikus produktivitātes un konkurētspējas novērtēšanas procesam ir jākḷūst par neatṇemamu daļu politikas veidošanā.

Kopumā jāpiekrīt secinātajam monogrāfijā "Produktivitātes celšana: tendences un nākotnes izaicinājumi”, ka Latvijā ar produktivitāti saistīto aspektu pētǐšana ir fragmentāra un tai trūkst sistēmiskas pieejas. Pētījumi ir veikti pārsvarā makrolīmenī, turklāt uz uzņēmuma līmeņa datiem balstīto pētỉjumu ir visai maz, bet starpnozaru (mezolīmeņa) aspekti praktiski nav analizēti, kas lielā mērā saistīts ar datu pieejamību. Tas ierobežo iespējas izstrādāt uz pētījumiem balstītas un zinātniski pamatotas rekomendācijas struktūrpolitikas veidošanā. ${ }^{12}$ Covid-19 pandēmijas ietekme uz produktivitāti Latvijā nav pētīta vispār, un šis ziņojums ir pirmais, kurā tiek vērtēta pandēmijas ietekme. Tiesa, ir pagājis pārāk maz laika, lai izdarītu tālejošus secinājumus par šis pandēmijas ietekmi uz produktivitāti.

12 Šteinbuka, I. (zin. red.). (2019). Produktivitātes celšana: tendences un nākotnes izaicinājumi. Rīga: LU Akadēmiskais apgāds, 146. lpp. Pieejams: https://www.apgads.lu.lv/fileadmin/user_upload/lu_portal/ apgads/PDF/Monografijas/Produktivitates_celsana/Produktivitate.pdf 


\section{Produktivitātes kopējā dinamika}

Produktivitāte Latvijā kopš 1996. gada ir pieaugusi gandrīz 3 reizes. Tomēr produktivitātes pieauguma tempiem Latvijā ir tendence sarukt. Straujāks pieaugums bija vērojams līdz 2008. gadam, it īpaši pēc Latvijas pievienošanās ES, kas kḷuva par nozīmīgu stimulu ārvalstu investīciju ieplūdei, galvenokārt parādu veidojošo plūsmu veidā (1. attēls).

Globālā finanšu krīze ietekmēja ne tikai ekonomisko aktivitāšu samazinājumu, bet arī produktivitātes dinamiku. Pirmajos divos ekonomikas recesijas gados (2008. un 2009. gadā) tā samazinājās par gandrīz 3\%. Tomēr jāatzīmē, ka salīdzinājumā ar IKP apjoma kritumu (par 17,4\%) produktivitātes samazinājums bija nenozīmīgs un to noteica galvenokārt spēcīgas korekcijas darba tirgū.

Kopš 2010. gada ir atsākusies produktivitātes pozitīva dinamika, tomēr tā ir daudz mērenāka nekā pirms krīzes. Laika periodā no 2011. līdz 2019. gadam produktivitāte ik gadu vidēji pieauga par 2,6\%, t. i., 2,5 reizes lēnāk nekā līdz 2007. gadam. Produktivitātes pieaugums samazinājums pèc 2008. gada ir saistīts ar lēno darbaspēka un kapitāla transformāciju uz zinātnesietilpīgām darbībām. Finanšu krīze ir pasliktinājusi kredītu pieejamību, kavējot kapitāla padzị̣ināšanos un ieguldījumus inovācijās.

Lai arī Latvijas produktivitātes pieauguma tempi ir vieni no straujākajiem Eiropas Savienības valstīs, salīdzinājumā ar ES augsti attīstītajām valstīm joprojām saglabājas liela atpalicība. 2019. gadā produktivitātes līmenis Latvijā bija tikai

\section{1. attēls. Latvijas pievienotās vērtības, nodarbinātības un produktivitātes pieauguma tempi (salīdzinājumāa ar iepriekšējo gadu, procentos)}

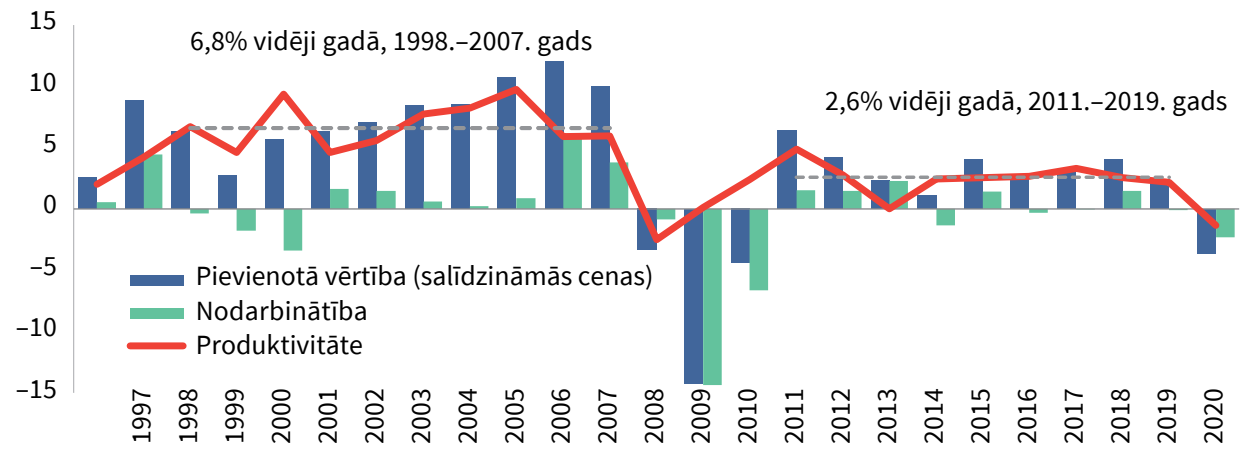




\section{2. attēls. Pievienotās vērtības un produktivitātes pēc nodarbināto skaita un nostrādātajām stundām dinamika (salīdzinājumā ar iepriekšējā gada atbilstošo ceturksni, sezonāli neizlīdzināti dati, procentos)}

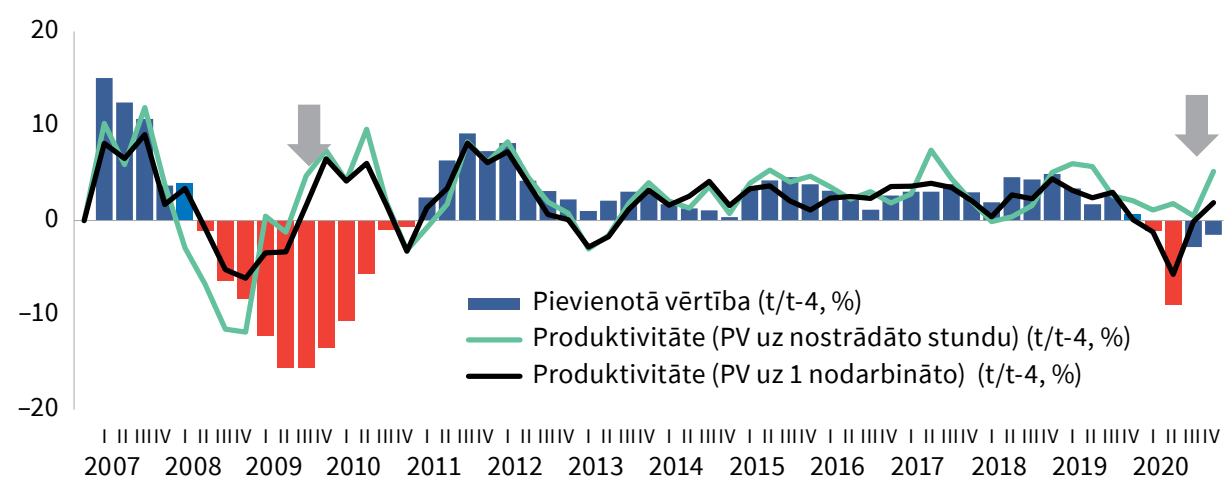

Avots: Eurostat, autoru aprēḳins.

49,8\% (68,8\% pēc PPS) no ES vidējā līmeņa, un tas ir viens no zemākajiem rādītājiem Eiropas Savienībā. ${ }^{13}$ Vienlaikus ir jāsecina, ka, tuvojoties ES vidējām līmenim, produktivitātes konverǵences tempi kḷūst arvien lēnāki un pieaug risks iekḷūt "vidējā ienākuma slazdā".

Covid-19 pandēmija ir radījusi globāla mēroga spēcīgu un paliekošu ietekmi uz sociālekonomisko situāciju. Līdzīgi kā gandrīz visās pasaules valstīs, arī Latvijā Covid-19 pandēmijas dēl ekonomika 2020. gadā nonāca recesijā un ir būtiski ietekmēts darba tirgus. Protams, tas ietekmē arī produktivitāti. Tomēr tā ietekme uz produktivitāti ir neskaidra. Rēķinot pievienoto vērtību pret nodarbināto skaitu, produktivitāte Latvijā 2020. gadā samazinājās par 1,3\%, bet pret kopējo nostrādāto stundu skaitu tā saglabājās ar pozitīvu pieaugumu visos 2020. gada ceturkšños (2. attēls).

Kā redzams 2. attēēā, "normālas" ekonomikas izaugsmes apstākḷlos produktivitātes izmaiņas ir līdzīgas, rēķinot pievienoto vērtību gan pret nodarbināto

13 Vairākos pētījumos produktivitātes līmeņa salīdzinājumam starp valstīm tiek lietots rādītājs IKP pēc PPS uz vienu nodarbināto. Autori norāda, ka reālajā ekonomikā starptautiskajos tirgos uzṇēmumi ar savām precēm un pakalpojumiem konkurē faktiskajās cenās, kas netiek korigètas ar atšķirīgajiem izmaksu līmeņiem valstīs (PPS). Piemēram, izejvielas uzņēmumi iegādājas par pasaules cenām. Lìdz ar to korektāk Latvijas uzṇēmēju konkurētspēju parāda produktivitāte, kas tiek aprēḳināta kā IKP faktiskajās cenās uz vienu strādājošo. Arī rēḳinot produkcijas vienības nominālās darbaspēka izmaksas (nominālo un reālo ULC), kas ir viens no konkurētspējas indikatoriem, produktivitāte netiek pārrēḳināta pēc PPS. Tāpēc, analizējot produktivitātes konverǵences procesu, autori izmanto rādītāju IKP faktiskajās cenās uz vienu strādājošo, nevis IKP pēc PPS uz vienu strādājošo. 
skaitu, gan pret kopējo nostrādāto stundu skaitu. Krīzes ietekmē rezultāti ir loti atšķirīgi. Tas pamatā ir saistīts gan ar darba tirgus korekciju īpatnībām, gan uzņēmumu vērtējumā gaidāmo krīzes ilgumu un dziļumu.

Covid-19 pandēmijas ietekme ir mainījusi ne tikai darba tirgu, bet arī statistikas iestāžu spēju mērīt to. Uzṇēmumu îslaicīga slēgšana, attālināta darba pieaugums un sociālās distancēšanās ieviešana ietekmē datu vākšanu. Valdības atbalsta pasākumi, piemēram, dīkstāves pabalsti, ietekmē darba produktivitātes uzskaiti (izlaide pret nodarbināto skaitu), jo cilvēks var nestrādāt (atrasties dīkstāvē), bet statistika to uztver kā strādājošo.

Šajā gadījumā piemērotāks rādītājs produktivitātes noteikšanā, šķiet, ir to aprēḳināt kā izlaides attiecību pret nostrādātajām cilvēkstundām. ${ }^{14}$ Tomēr arī šā rādītāja izmantošana nav ideāla, ja tiek lietotas īsāka darba stundu shēmas. ${ }^{15}$

Balstoties tikai uz īstermiņa statistikas datiem, nav iespējams pilnībā novērtēt Covid-19 pandēmijas ietekmi uz produktivitātes turpmāko dinamiku. Pieejamie statistikas dati atspogul̦o korekcijas produktu, darba un kapitāla tirgos, reagejejot uz pandēmijas apkarošanas un ekonomikas stabilizācijas pasākumiem. Būtisks ir jautājums par Covid-19 pandēmijas ilgtermin̦a ietekmi uz biznesa modeḷu un sabiedrības uzvedības maiṇu. Acīmredzams, ka izmaiṇas notiek, bet vēl joprojām ir ļoti liela nenoteiktība par to noturību un ietekmi uz produktivitātes ilgtermiņa tendencēm.

\section{Produktivitātes analīze pamatnozaru griezumā un tehnologiskās intensitātes strukturālās izmaiṇas}

Datu analīze liecina, ka laika periodā no 2011. līdz 2019. gadam vairākās nozarēs konverǵences tempi ir bremzējušies (3. attēls). Tādas nozares, piemēram, ir lauksaimniecỉba, administratīvie pakalpojumi, informācijas un komunikācijas pakalpojumi, profesionālie un zinātniskie pakalpojumi, kurās produktivitātes konverğence ES vidējām līmenim straujāk notika līdz 2010. gadam, bet turpmākajos gados tā bija ḷoti vāja. Konvergences dinamikas palēnināšana varētu liecināt par "produktivitātes slazdu", kura pārvarēšanai ir nepieciešams paātrināt strukturālās reformas un būtiski uzlabot inovatīvos risinājumus.

Zemo produktivitātes līmeni Latvijas tautsaimniecībā lielā mērā nosaka izteikti zemā produktivitāte apstrādes rūpniecībā strukturālo faktoru dēḷ. 2019. gadā tā bija tikai 38\% (52\% pēc PPS) no ES vidējā līmeṇa. Kā rāda attīstìto

\footnotetext{
14 European Commission. (2020). European Economic Forecast: Autumn 2020, Institutional Paper 136, November, p. 48. Pieejams: https:/ec.europa.eu/info/publications/economic-and-financial-affairs-publications_en

15 Turpat, 49. lpp.
} 
3. attēls. Latvijas produktivitātes plaisas ar Eiropas Savienību izmaiṇas laika periodā no 2000. lídz 2019. gadam ( $E S-28=100)$

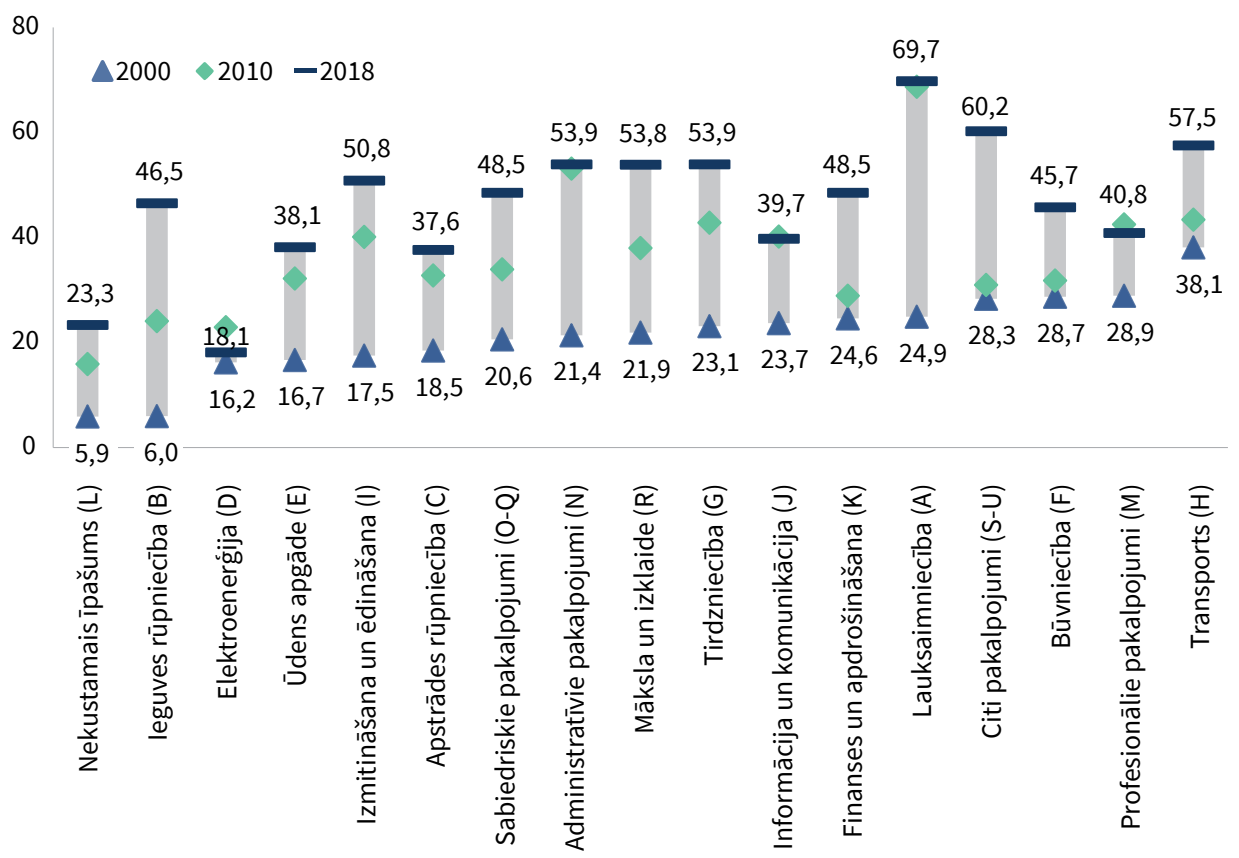

Avots: Eurostat, autoru aprēḳins.

valstu pieredze, tieši apstrādes rūpniecībai ir raksturīga potenciāli augstāka inovācijas kapacitāte.

Latvijas apstrādes rūpniecības struktūrā dominē zemo tehnoloǵiju nozares, kas pēdējos gados veido vairāk nekā pusi no apstrādes rūpniecības kopējās pievienotās vērtības, un tas ir gandrīz pusotras reizes vairāk nekā vidēji Eiropas Savienībā. Tas ir skaidrojams ar tradicionālo nozaru (pārtikas rūpniecība un kokapstrādes rūpniecība) nozīmīgo dal̦u, kas kopā veido gandrīz pusi no apstrādes rūpniecības kopējās pievienotās vērtības, un tas ir gandrīz pusotras reizes vairāk nekā vidēji Eiropas Savienībā. 2019. gadā augsto tehnoloǵiju nozarēs bija nodarbināti tikai 4\% no kopējā nodarbināto skaita apstrādes rūpniecībā, kas ir gandrīz divreiz mazāk nekā vidēji Eiropas Savienībā. Zemās un vidēji zemās tehnologisiskās intensitātes nozarēs nodarbinātie veidoja gandrīz 87\%, t. i., pusotras reizes vairāk nekā ES valstīs vidēji (4. attēls).

Pēdējos gados produktivitāte augsto un vidēji augsto tehnolog̣iju nozarēs pieaug straujāk nekā zemākās tehnologiskās intensitātes nozarēs (5. attēls). Tomēr 
4. attēls. Apstrādes rūpniecības struktūra pēc tehnoloğiskās intensitātes

(2019. gads, pēc nodarbināto skaita, procentos)

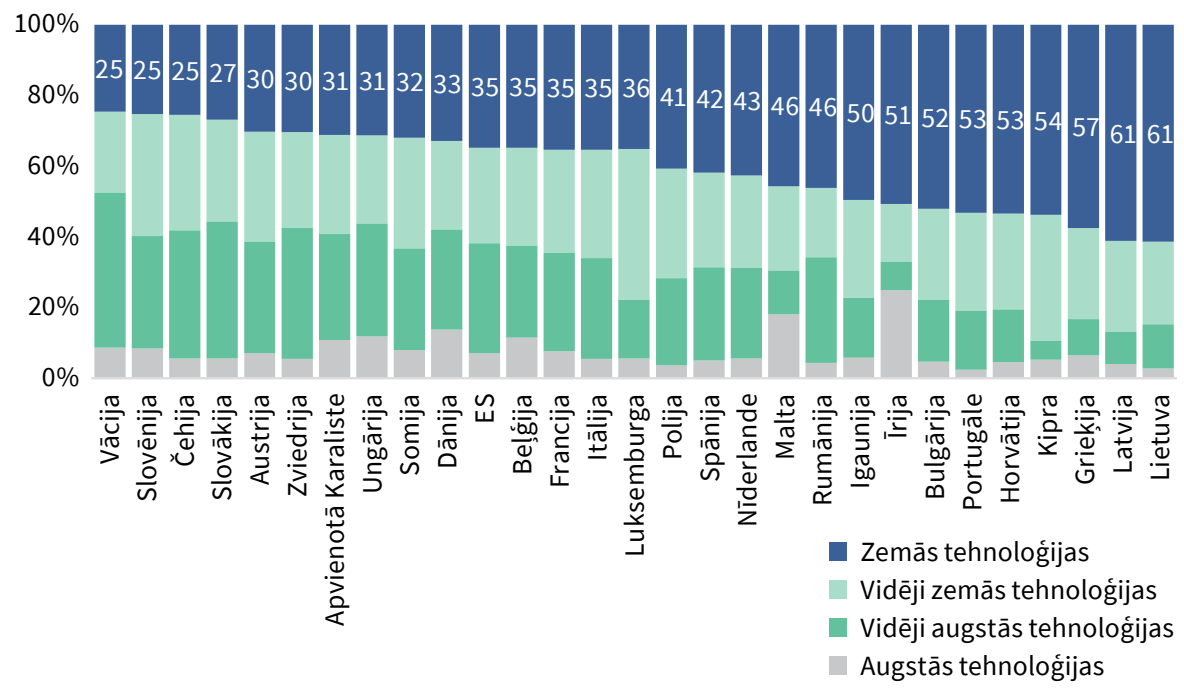

Avots: Eurostat, autoru aprēḳins.

5. attēls. Produktivitātes pieauguma tempi apstrādes rūpniecībā pēc tehnologiskās intensitātes (vidēji gadā, procentos)

\begin{tabular}{|c|c|c|c|}
\hline & 1997.-2007. gads & 2008.-2010. gads & 2011.-2019. gads \\
\hline Zemo tehnologiju nozares & 5,4 & 1,8 & 2,6 \\
\hline Vidēji zemo tehnoloǵiju nozares & 14,4 & 6,9 & 1,4 \\
\hline Vidēji augsto tehnoloǵiju nozares & 7,9 & 5,2 & 2,8 \\
\hline Augsto tehnologiju nozares & 6,6 & 2,7 & 3,6 \\
\hline
\end{tabular}

Avots: Eurostat, autoru aprēḳins, 2019. gada novērtējums.

šo nozaru devums kopējā produktivitātes kāpumā joprojām ir neliels, galvenokārt to nelielā īpatsvara dẹl apstrādes rūpniecības kopējā pievienotajā vērtībā.

Produktivitātes līmeņa paaugstināšanā būtiska nozīme ir tehnologiskiem faktoriem, piemēram, ražošanas modernizācijai, esošo tehnologiju pilnveidošanai un jaunu tehnoloǵiju ieviešanai. Pāreja no vecām uz jaunākām tehnolog̣ijām sekmē produktivitātes pieaugumu uzṇēmuma un nozares līmenī. Tāpat šādu 


\section{6. attēls. Strukturālo izmainu ietekme uz produktivitāti tirgus sektorā} (vidēji gadā, procentos)

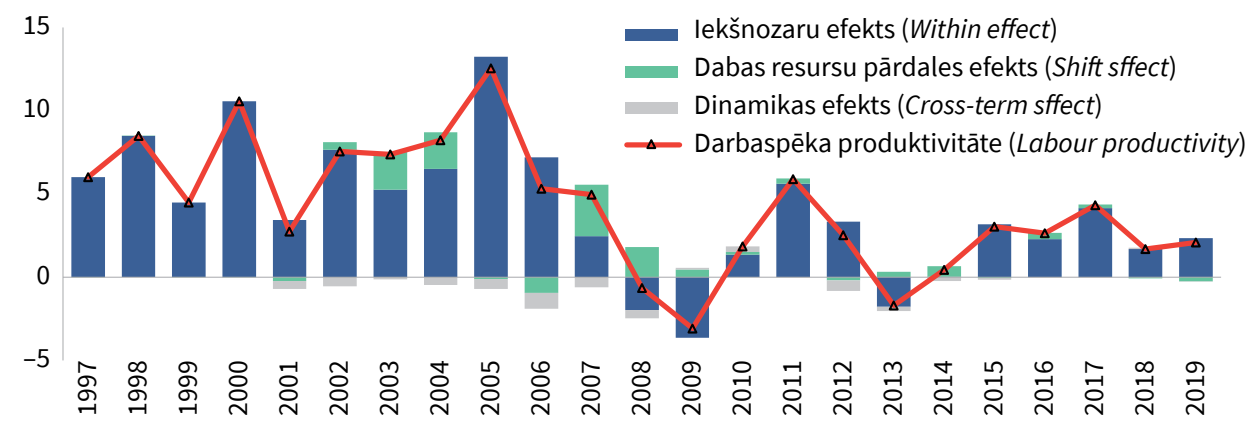

Avots: Eurostat, autoru aprēķins.

pārmaiṇu sniegums kopējā produktivitātes līmeṇa paaugstināšanā lielā mērā ir atkarīgs no resursu pārdales no zemākās uz augstākās produktivitātes nozarēm, kā arī uz nozarēm ar straujāku produktivitātes dinamiku.

Lietotā strukturālo izmaiņu ietekmes analīzes (shift share analysis) metode rāda, ka laika periodā no 1997. līdz 2019. gadam produktivitātes dinamiku Latvijā ietekmēja galvenokārt iekšnozaru efekts (within-sector effects), tātad produktivitātes uzlabojumi pārsvarā notiek katrā atsevišḳā nozarē, ko ietekmē prasmīgāks menedžments, tehnoloǵiju pilnveidošana, inovācijas, nodarbināto kvalifikācijas celšana, labvēlīga tirgus konjunktūra un citi nozarei specifiski faktori (6. attēls).

Nodarbinātība pieaug nozarēs ar produktivitāti virs tautsaimniecības vidējā līmeņa, piemēram, datoru un elektronisko iekārtu ražošanā, un vienlaikus samazinās nodarbināto skaits dažās zemās produktivitātes nozarēs, piemēram, vieglajā rūpniecībā. Tomēr joprojām liels darba vietu skaits tiek radīts nozarēs ar relatīvi zemāku produktivitātes līmeni, piemēram, izmitināšanas un ēdināšanas pakalpojumu nozarē (7. attēls).

Kopumā darba resursu pārdale Latvijā par labu produktīvajām nozarēm ir nepietiekama, lai būtiski ietekmētu tautsaimniecības kopējā produktivitātes līmeņa straujāku kāpumu. Kā apgalvo Saimons Kuzṇets, "nav iespējams sasniegt augstu pieauguma tempu uz vienu iedzīvotāju vai uz vienu darba ņēmēju bez atbilstošām būtiskām izmaiṇām dažādu nozaru īpatsvarā”. ${ }^{16}$

16 Kuznets, S. (1979). Growth and structural shifts. In: Galenson, W. (ed.) Economic Growth and Structural Change in Taiwan. The Postwar Experience of the Republic of China. Cornell University Press. London. 


\section{7. attēls. Izmaiṇas nodarbināto struktūrā nozaru agregācijā pa tehnologiju līmeṇiem ar dažādu produktivitātes lïmeni 2011.-2019. gadā}

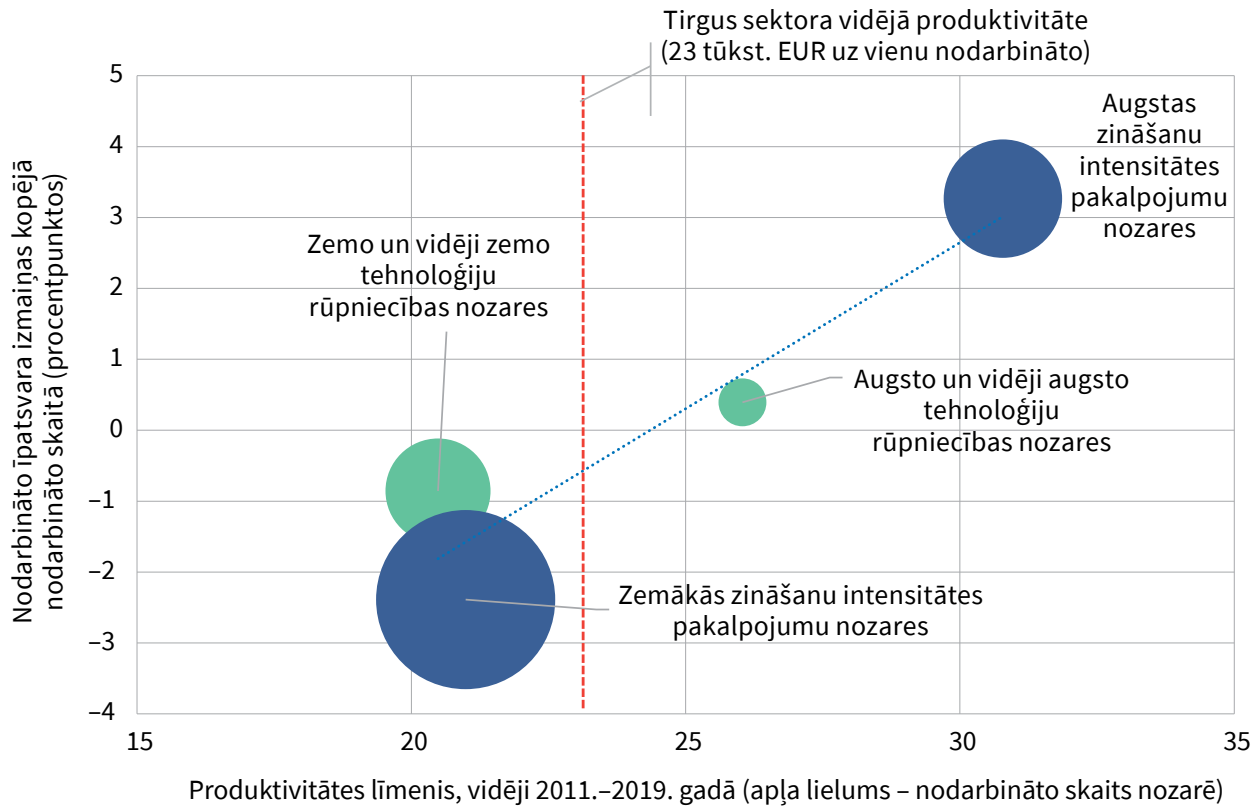

Avots: Eurostat, autoru aprēķins.

\section{Nozīmīgākie produktivitātes pieaugumu veicinošie faktori}

Produktivitātes pieaugumu nosaka vairāki fundamentāli faktori. Tie ir saistīi ar investīcijām un kapitāla intensitātes palielināšanu, spēju iekḷauties globālās vērtỉbu ķēēēs un eksporta potenciāla palielināšanu, inovācijām un ieguldỉjumiem pētniecībā un attīstībā, jaunu produktu, pakalpojumu un metožu izstrādi, jauno tehnologiju radītajām priekšrocībām un zinātniski tehniskā progresa lomu ražošanas intensifikācijā, jo īpaši digitalizācijas jomā, kā arī ieguldījumiem cilvēkkapitālā, uzlabojot iedzìvotāju prasmes un iemaņas vairojot zināšanu kopumu, kas motivē cilvēku būt produktīvam.

Būtiska nozīme produktivitātes palielināšanā ir arī ražošanas procesa organizēšanai un vadībai, ražošanas specializācijai un koncentrācijai, ražotņu teritoriālam izvietojumam, kā arī starpnozaru horizontālo un vertikālo saikņu izveidei.

Šeit mēs analizēsim dažus no iepriekš minētajiem faktoriem, proti, inovāciju, ieguldījumus pētniecībā un attīstībā (P\&A), digitalizāciju un cilvēkkapitālu. 


\section{8. attēls. Latvijas vērtējums konkurētspējas pīlāros $\mathrm{GCI} 4.0$ reitingā 2019. gadā}

(distance līdz līderim, vērtējums no 0 līdz 100)

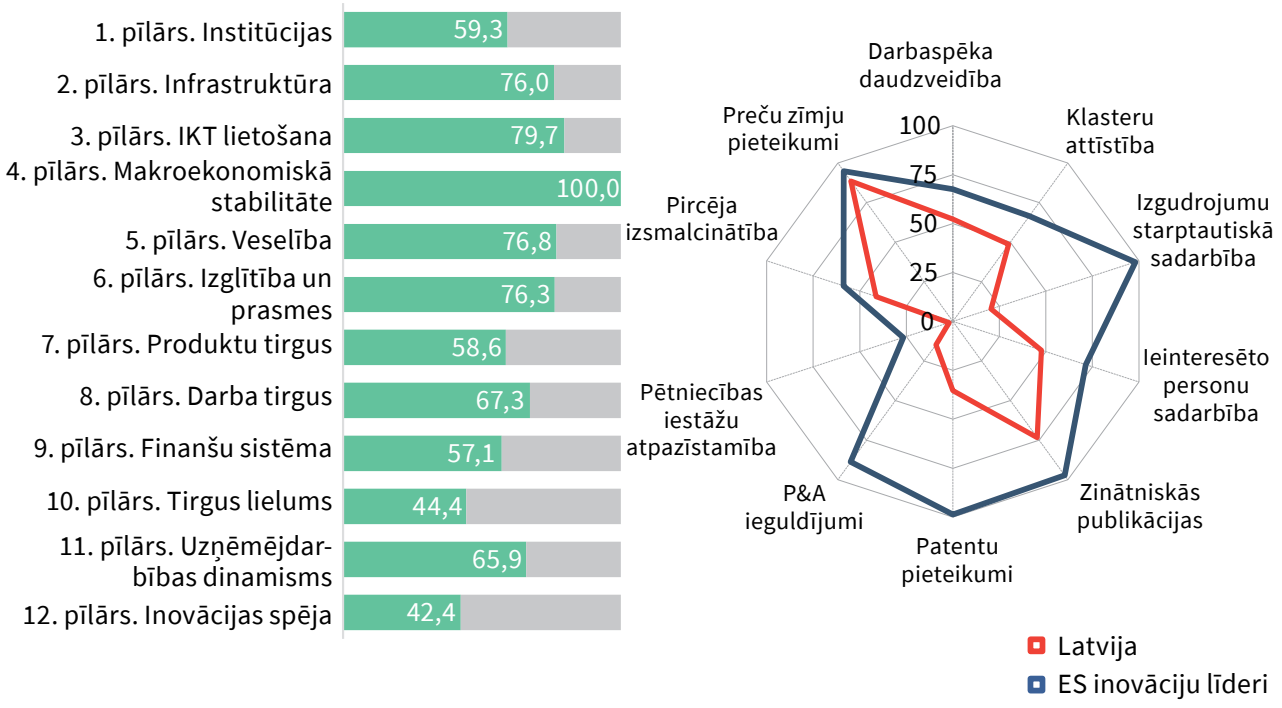

Avots: The Global Competitiveness Report 2019. http://www3.weforum.org/docs/WEF_

TheGlobalCompetitivenessReport2019.pdf, autoru veidots.

Kā rāda dažādi pētījumi un reitingi, Latvijas vājākais punkts ir inovācijas. Pasaules Inovācijas indeksā 2020 (Global Innovation Index 2020) Latvija ir ierindojusies 36. vietā starp 131 apsekoto valsti. ${ }^{17}$ Eiropas Komisijas gadskārtējā Eiropas inovācijas rezultātu pārskatā 2020 (European Innovation Scoreboard 2020) Latvija 27 ES valstu vidū ir 23. vietā. ${ }^{18}$ No ES inovatīvajām ekonomikām Latvija visvairāk atpaliek šādās jomās: pētniecisko iestāžu kapacitāte, izdevumi pētniecībai un attīstībai, starptautiskie izgudrojumi, patentu pieteikumi u. c.

Pasaules Ekonomikas foruma (WEF) publicētajā Pasaules konkurētspējas reitingā 2019. gadā Latvija pēc inovācijas spējas ir ierindota 52. vietā starp 141 pasaules valsti; vērtējums - 42 (8. attēls). ${ }^{19}$ Šà pīlāra vērtējumā Latvijai ir vislielākā atpalicība ne tikai no ES inovatīvajām ekonomikām, bet arī no visām ES valstīm, izṇemot Rumāniju. Latvijas zemā inovatīvā kapacitāte nav labvēlīga nākotnei, un

17 https://www.wipo.int/edocs/pubdocs/en/wipo_pub_gii_2020/lv.pdf

18 https://ec.europa.eu/docsroom/documents/42981

19 http://www3.weforum.org/docs/WEF_TheGlobalCompetitivenessReport2019.pdf 


\section{9. attēls. P\&A investīcijas Latvijā}

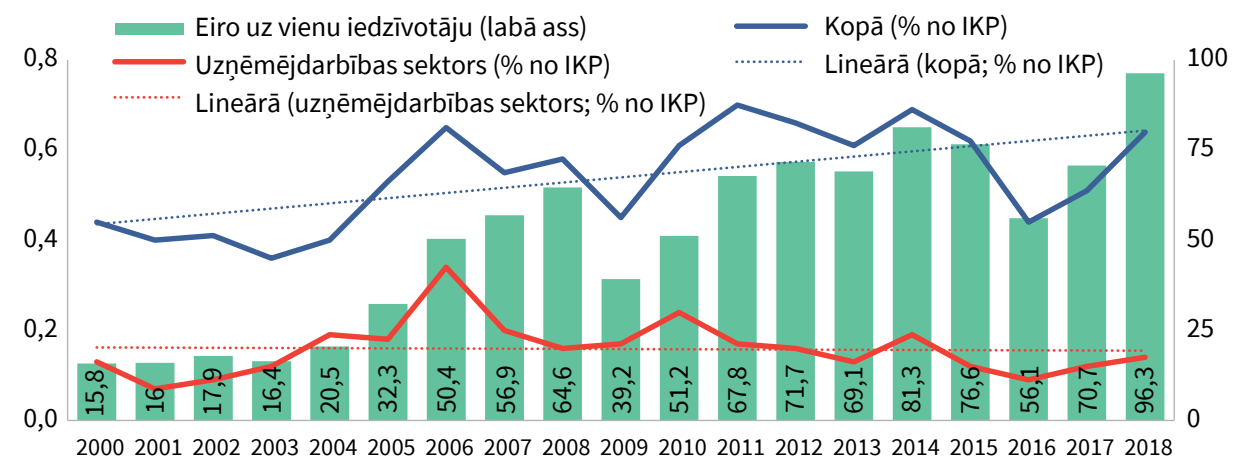

Avots: Eurostat, autoru aprēkinins.

šobrīd to būtiski ierobežo vāja starptautiskā sadarbỉba zinātnes un pētniecības jomā, vāja zinātnieku un uzṇēmēju sadarbỉba, zems investīciju līmenis pētniecībā un attīstībā un citi faktori.

Nelielie ieguldījumi P\&A negatīvi ietekmē Latvijas centienus sasniegt augstāku ražīgumu. Kopš 2000. gada investīciju P\&A līmenis (\% no IKP) ir palielinājies gandrīz 1,5 reizes, ko noteica galvenokārt investīciju P\&A būtisks kāpums līdz 2007. gadam. Turpmākajos gados tas vidēji bija 0,6\% līmenī no IKP, kas ir divreiz mazāks par Nacionālajā attīstības plānā 2020 izvirzìto mērḳi - sasniegt $1,5 \%$ no IKP līdz 2020. gadam ${ }^{20}$ (9. attēls).

Laika periodā no 2010. līdz 2018. gadam P\&A kopējais finansējums uz 1 iedzīvotāju sasniedza vidēji 74 EUR gadā, kas ir tikai 13\% no ES vidējā rādītāja. Pēc šā rādītāja Latvija būtiski atpaliek no vairuma ES dalībvalstu, kā arī no Baltijas kaimiņvalstìm Lietuvas un Igaunijas.

Privātā sektora finansējums ir neliels - aptuveni ceturtā daḷa no kopējiem ieguldījumiem P\&A (0,2\% no IKP), kas ir daudz zemāks nekā vidēji ES, kur uzṇēmēji nodrošina vairāk nekā pusi no kopējā $P \& A$ ieguldījumu finansējuma. Ilgtermiņa skatījumā uzņēmumu ieguldījumu P\&A līmenis nav pieaudzis, pēdējos gados pat ir vērojama lejupvērsta tendence.

Uzṇēmēju ieguldījumu zemo līmeni zinātniski pētnieciskajā darbā ietekmē gan piedāvājuma faktori (piemēram, pētniecības iestāžu kapacitāte), gan

20 Pārresoru koordinācijas centrs. (2012). Latvijas Nacionālais attīstības plāns 2014.-2020. gadam. Rīga, 18. lpp. Pieejams: https://www.pkc.gov.lv/sites/default/files/inline-files/20121220_NAP2020\%20apstiprinats\%20Saeima_4.pdf 
pieprasijuma faktori, t. i., P\&A intensīvo nozaru (it īpaši apstrādes rūpniecības nozaru) zems īpatsvars tautsaimniecības struktūrā. Augstās un vidēji augstās P\&A intensitātes nozares Latvijā 2010.-2018. gadā vidēji veidoja 5,2\% no IKP, tai skaitā apstrādes rūpniecībā - 2\% no IKP. Savukārt vairumā ES dalībvalstu šo nozaru daļa ir daudz lielāka.

Statistikas dati liecina, ka starp tautsaimniecības struktūras rādītājiem un uzņēmēju ieguldījumiem P\&A pastāv pozitīvā sakarība. Valstīs ar augstāku P\&A intensīvo nozaru daḷu tautsaimniecības struktūrā arī uzņēmēju ieguldījumi P\&A ir lielāki (10. attēls).

Vienlaikus jānorāda, ka ieguldījumi inovācijā ir daudz plašāks jēdziens nekā ieguldījumi pētniecībā un attīstībā. Un ne visi uzṇēmumi, kas veiksmīgi ievieš inovācijas, noteikti ir pētniecības un attīstības veicēji (finansētāji). Daudzi no tiem ir ieviesuši jaunas tehnolog̣ijas, kuras paši nav izstrādājuši (t. i., nav ieguldījuši $P \& A)$. Taču ieguldījumi P\&A var arī vāji ietekmēt uzṇēmumu inovatīvo sniegumu.

Ekonomikas specializācija ir salīdzinoši noturīga, un strukturālās izmaiņas notiek ḷoti lēni. Tam ir nepieciešami spēcīga struktūrpolitika (arī ar selektīvu raksturu). Turklāt, saglabājoties esošai nozaru struktūrai, ieguldījumi P\&A

\section{0. attēls. Uzṇēmējdarbības un tautsaimniecības struktūra un uzṇēmējdarbības sektora ieguldijumi P\&A ES dalībvalstīs 2018. gadā (procentos)}

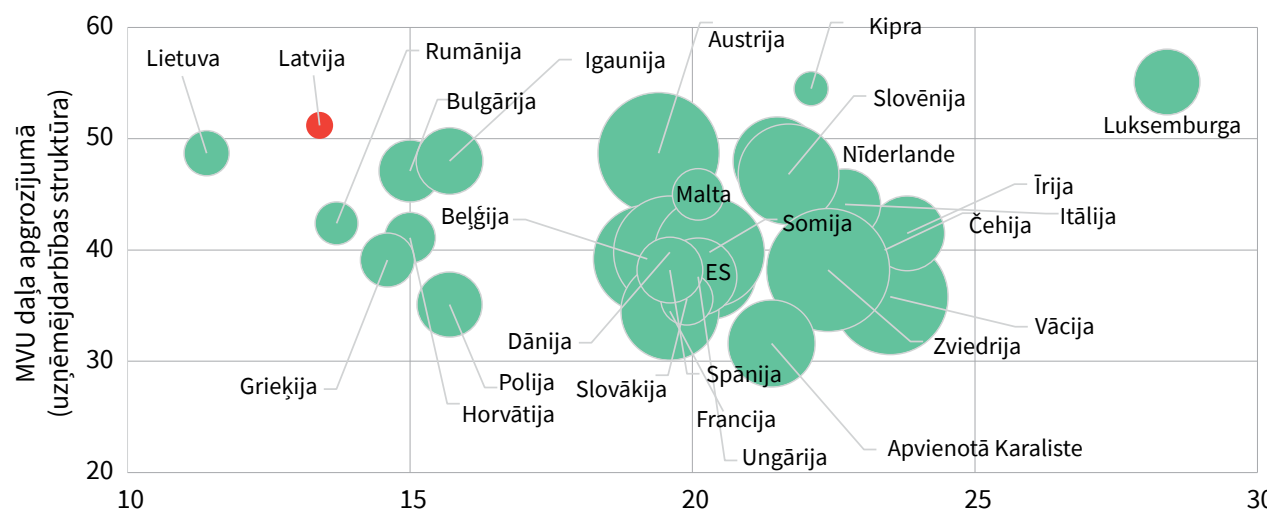

Nodarbināto īpatsvars augstas un vidēji augstas tehnoloǵiskās intensitātes aktivitātēs (tautsaimniecības struktūra)

Apḷa lielums - privātā sektora izdevumi P\&A, \% no IKP.

Avots: Eurostat, EIS dati, autoru veidots. 
ilgstoši būs salīdzinoši zemā līmenī, kas atbilst Latvijas ekonomikas specializācijai un zināmā mērā ir dabisks līmenis.

Kopumā jāsecina, ka Latvijas ilgstoši zemo P\&A ieguldījumu līmeni būtiski nosaka strukturālie šḳēršli, no kuriem nozīmīgākie ir:

- P\&A intensīvo nozaru ${ }^{21}$ zems īpatsvars tautsaimniecības struktūrā;

- zems apstrādes rūpniecības īpatsvars IKP;

- apstrādes rūpniecībā dominē zemo un vidēji zemo tehnoloǵiju nozares, un joprojām nepietiekams uzņēmumu skaits ir iesaistīts globālās vērtību ķēdēs, vai arī tie ir iesaistījušies globālo vērtību ķē̌zu aktivitātēs ar zemu zināšanu ietilpību un ienesīgumu;

- tautsaimniecības struktūrā pārmērīgi daudz ir mikrouzṇēmumu, kuriem nav kritiskās masas, lai sāktu eksporta aktivitātes, tādējādi pārvarot apjoma šķēršlus, ko rada ierobežots iekšējais tirgus.

Minētie strukturālie šḳērṣ̌ı ne tikai nosaka privātā sektora vājo kapacitāti ieguldijjumiem $P \& A$, bet arī to zemo pieprasījumu pēc P\&A pētījumiem. Saskañā ar CSP datiem no kopējā uzṇēmumu finansējuma apmērām tikai piektā daļa tiek ieguldīta pētniecībā augstskolās un zinātniskajos institūtos. Tas norāda uz augstskolu, zinātnisko institūtu un privātā sektora uzṇēmumu nepietiekamu sadarbību P\&A jomā.

Latvijas pētniecības un inovācijas sistēmas attīstību kavē arī atbilstošas kvalifikācijas speciālistu trūkums un pētniecības un inovācijas sistēmas pārvaldības sadrumstalotība Latvijā. Eiropas Komisijas ziņojumā norādīts, ka prasmju trūkums un vēl joprojām vājās saiknes starp pētniecību un rūpniecību, kā arī vājā sadarbība rūpniecỉbas iekšienē ir nozīmīgi faktori, kas kavē Latvijas pētniecības un inovāciju sistēmas attīstību. ${ }^{22}$

Latvijas sniegumam inovāciju jomā varētu nākt par labu aktīvāka lielāko valsts uzṇēmumu iesaistǐšanās, kuriem ir resursi un kuri varētu veikt būtiskus ieguldïjumus.

Ir jāmaina sabiedrības attieksme (inovācijas nav hobijs, bet nepieciešams labklājības pieauguma nosacījums) un attiecīgi jāuzlabo inovāciju stimuli. Tāpat jāuzlabo inovāciju sistēmas tiesiskais regulējums, tostarp iesaistīto iestāžu un

21 OECD Taxonomy of Economic Activities Based on R\&D Intensity. High R\&D intensive activities (2-digit definition): Basic pharmaceutical products and pharmaceutical preparations; Computer, electronic and optical products; Scientific research and development. Medium-high R\&D intensive activities (2-digit definition): Chemicals and chemical products; Electrical equipment; Machinery and equipment n.e.c; Transport equipment; Publishing activities; IT and other information services; Scientific research and development. Pieejams: https://stats.oecd.org/DownloadFiles.aspx? HideTopMenu=yes\&DatasetCode=STANI4_2016\&lang=en

22 Eiropas Komisija. (2020). Komisijas dienestu darba dokuments. Ziņojums par Latviju - 2020. gads. Brisele, 26.02.2020. SWD (2020) 513 final. Pieejams: https://eur-lex.europa.eu/legal-content/LV/TXT/ $\mathrm{PDF} /$ ?uri=CELEX:52020SC0513\&from $=\mathrm{EN}$ 


\section{1. attēls. Digitālās ekonomikas un sabiedrības indeksa (DESI) 2020. gada vērtējums}

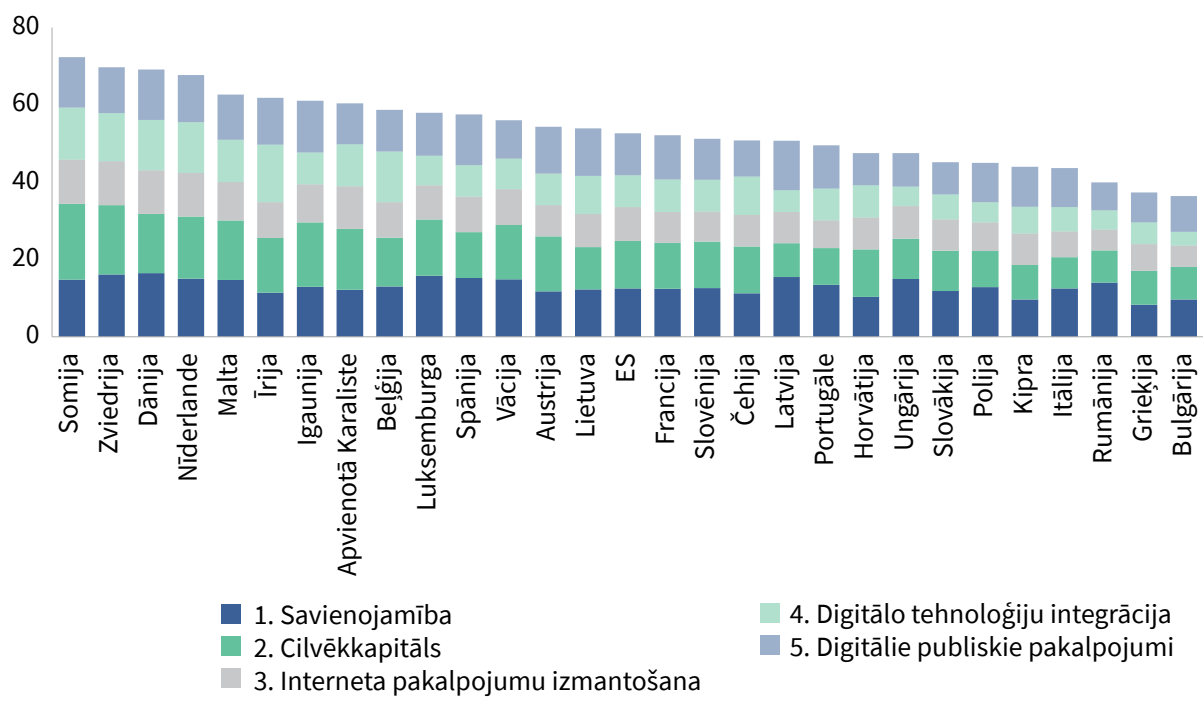

Avots: Eiropas Komisija, https://ec.europa.eu/digital-single-market/desi

nevalstisko organizāciju pienākumi un atbildība, valsts atbalsta sistēma intelektuālā īpašuma radīšanā, komercializācijā un praktiskā īstenošanā. Valstij jākoordinē izcilu inovatīvu produktu komercializācija Latvijā. Jāizstrādā ekonomiskais pamatojums un tiesiskais regulējums inovāciju iepirkumam.

Kopumā jāsecina, ka Latvijas ekonomikas ilgtspējīgas izaugsmes problēma ir jārisina kompleksi ar konkurētspējas palielināšanas problēmām, kas savukārt nav iespējams bez esošā ekonomikas model̦a maiņas. Jauna zināšanās un inovācijās balstītā ekonomikas modeḷa veidošanā īpaša uzmanība ir jāpievērš esošajām problēmām - institucionālās vides kvalitātei, uzṇēmējdarbỉbas dinamisma palielināšanai, inovācijas spējas stiprināšanai.

Piln̄̄ga digitalizācijas iespēju izmantošana ir būtiska, lai uzturētu produktivitāti un uzlabotu dzīves līmeni. Eiropas Komisija kopš 2014. gada publicē Digitālās ekonomikas un sabiedrības indeksu (DESI), kas atspoguḷo dalībvalstu progresu digitālajā jomā. DESI 2020. gada rangā Latvija ieṇem 18. vietu ${ }^{23}$ starp 28 valstīm (11. attēls). Salīdzinājumā ar 2019. gadu Latvijas pozīcija pasliktinājusies par trim vietām.

${ }^{23}$ https://ec.europa.eu/digital-single-market/desi 
Latvijas digitālās attīstības līmenis kopumā atbilst ES vidējam līmenim. Savienojamības (4. vieta) un digitālo publisko pakalpojumu (5. vieta) ziņā Latvijas rādītāji pārsniedz ES vidējos rādītājus. Latvijas galvenās stiprās puses ir attīstìtais àtrdarbīgās platjoslas pārklājums (nākamās paaudzes piekḷuve, NGA) un gandrīz pilnīgs vidējais $4 \mathrm{G}$ pārklājums (99\%; ES vidējais rādītājs - 96\%). Arī l̦oti augstas veiktspējas tīkliem pārklājuma rādītāji Latvijai ir divreiz lielāki nekā vidēji Eiropas Savienībā. Latvijai visi rādītāji digitālo publisko pakalpojumu jomā ir virs ES vidējiem rādītājiem. Nepārtraukti uzlabojās tiešsaistes publisko pakalpojumu nodrošināšana, un pieaug e-pārvaldes lietotāju skaits.

Interneta pakalpojumu lietošanas jomā Latvija ieņem 19. vietu DESI reitingā, un kopumā interneta pakalpojumu izmantošana Latvijā ir nedaudz zem ES vidējā līmen̦a - 84\% iedzìvotāju lieto internetu vismaz reizi nedẹl̦ā, kas ir par 3 procentpunktiem vairāk nekā pirms gada un ir tikai nedaudz zem ES vidējā rādìtāja - 85\%.

Viszemākais vērtējums ir cilvēkkapitāla un digitālo tehnologiju integrācijas jomā, kur Latvija DESI reitingā ieņem attiecīgi 24. un 23. vietu. Gan cilvēkkapitāla, gan digitālo tehnologiiju integrācijas jomā Latvija būtiski atpaliek arī no Lietuvas un Igaunijas.

2020. gada DESI ziņojumā ir atzīmēts, ka Latvijas uzņēmumi pilnvērtīgi neizmanto Lielo datu un mākoṇdatošanas nodrošinātās iespējas. Tikai $8 \%$ uzṇēmumu izmanto lielos datus (ES vidējais rādītājs - 12\%), 11\% izmanto mākoṇdatošanu (ES vidējais rādītājs - 18\%). Tikai $11 \%$ mazo un vidējo uzṇēmumu veic tirdzniecību tiešsaistē (ES vidēji - 18\%).

Arī ESAO pētījumos atzīmēts, ka salīdzinājumā ar ESAO dalībvalstīm Latvijas uzṇēmumi būtiski atpaliek digitālo tehnolog̣iju lietošanā, uzṇēmējiem trūkst digitālo prasmju un transformācijai nepieciešamo zināšanu, iemaņu, kā arī atbilstošu rīku (piemēram, produktivitātes rīku digitālajai tirdzniecībai, pārrobežu tirdzniecỉbas tiešsaistē u. tml.).

Kaut arī ātrgaitas platjoslas tīkla ieviešanas ziṇā Latvija pārsniedz ESAO un ES vidējo līmeni, tikai daži Latvijas uzṇēmumi izmanto jaunas digitālās tehnologijas, piemēram, lielo datubāzu analīzi, radiofrekvenču identifikācijas tehnologijas u. c.

Eiropas Komisija uzsver, ka uzlabojumus digitālo pakalpojumu integrācijā uzṇēmumos ierobežo augsti kvalificētu speciālistu trūkums. Lai arī aizvien vairāk iedzīvotāju izmanto internetbankas un e-pārvaldes pakalpojumus, pusei iedzīvotāju nav digitālo prasmju vai to līmenis ir zems. Latvijā ir viens no augstākajiem iedzīvotāju īpatsvariem dažādās vecuma grupās, kuriem ir zems vispārējo digitālo prasmju līmenis. Tas rada ne tikai digitālo prasmju nepietiekamību darba tirgū, bet arī kopumā kavē plašāku digitālo tehnologiju ienākšanu uzņēmumos, 
kā arī vietējā digitālo produktu tirgus attīstību. Digitālo pakalpojumu lietošanas paradumus nereti ietekmē arī e-pārvaldes pakalpojumu nepietiekama kvalitāte un lietotājorientētîbas trūkums, kas attur iedzīvotājus sākt izmantot e-pārvaldes pakalpojumus.

Iedzīvotāju digitālo prasmju uzlabošana ir priekšnosacījums, lai varētu izveidot iekḷaujošus darba tirgus, kā arī paaugstināt to uzṇēmumu produktivitāti, kuri patlaban visai maz izmanto digitālās priekšrocības. Reǵionos aizvien ir neizmantots platjoslas optiskā interneta pieslēguma potenciāls, kas nodrošinātu uzticamu un ātru digitālo infrastruktūru uzṇēmumiem, kā arī attālinātā darba iespējas nodarbinātajiem. Neraugoties uz pamatinfrastruktūras pieejamību reǵionu centros, elektronisko sakaru pakalpojumu piegāde iedzīvotājiem reǵionos aizvien nav iespējama, kamēr netiks nodrošināts "pēdējās jūdzes" pieslēgums un atbilstoša pakalpojumu nodrošināšanas politika.

Covid-19 izraisītā krīze atklāja digitalizācijas īpašu nozīmi attiecībā uz sabiedrības spēju ātri pielāgoties jaunajiem apstākḷiem. Tā parādīja arī Latvijas vājās puses un kḷuva par spēcīgu grūdienu straujākai digitālo tehnologiju ieviešanai vairākās jomās. Svarīgi arī turpmāk veicināt izpratni par digitālo tehnolog̣iju lietošanas plašām iespējām, kā arī pilnveidot valsts instrumentu klāstu digitālās transformācijas procesu atbalstam. DESI 2020 ziņojumā atzīmēts, ka īpaša uzmanība jāpievērš rādītājiem, kas ir būtiski spēcīgākai un noturīgākai digitālajai pārveidei un ekonomikas atvesel̦ošanai, jo īpaši l̦oti augstas veiktspējas tīkliem (VHCN) un 5G, digitālajām prasmēm, progresīvām digitālajām tehnologijām uzņēmumiem un digitālajiem publiskajiem pakalpojumiem. ${ }^{24}$

Kopumā jāsecina, ka Latvijā ir izveidojusies digitālā plaisa starp pilsētu un laukiem. Lielai dalai Latvijas iedzīvotāju trūkst digitālo pamatprasmju, kas viņiem liedz efektīvi lietot internetu. Digitālo tehnologiju integrācija uzṇēmumos ir krietni zem ES vidējā līmeņa. Latvijas sabiedrība nav pilnībā gatava ekonomikas digitālam izrāvienam. Latvijā ir viens no augstākajiem iedzīvotāju īpatsvariem dažādās vecuma grupās, kuriem ir zems vispārējo digitālo prasmju līmenis. Tas rada ne tikai digitālo prasmju nepietiekamību darba tirgū, bet arī kopumā kavē plašāku digitālo tehnologiju ienākšanu uzṇēmumos. Galvenajiem politikas virzieniem jābūt digitālo prasmju palielināšanai sabiedrībai kopumā, specifiski orientējoties uz katru mērķa grupu, lai novērstu nevienlīdzības risku nākotnē. Jāizstrādā visaptveroša uzņēmumu digitalizācijas stratēgija. Svarīgs instruments digitālajā laikmetā ir arī pastāvīgs dialogs ar uzṇēmējiem par jaunāko tehnologiju attīstību un digitālās ekonomikas tendenču ietekmi uz to darbību.

24 European Commission. Digitālās ekonomikas un sabiedrības indekss (DESI) 2020. gadā. Pieejams: https://ec.europa.eu/digital-single-market/en/scoreboard/latvia 
Svarīga nozīme digitālās ekonomikas apstākḷ̆os ir arī regulācijai. Politiku veidotājiem jāapzinās, ka ir jomas, kur ir ierobežotas iespējas piemērot jaunus biznesa modeḷus, tāpēc ir izaicinājums, kā veidot regulatīvos ietvarus, kad tirgū ienāk jauni biznesa model̦i. Pašreizējie regulatīvie modelii ir bāzēti uz institucionālo ietvaru, savukārt uzṇēmēji savā darbībā bāzējas nevis uz institucionālajiem ietvariem, bet uz konkrētām funkcijām. Būtiski strukturālo politiku virzieni ir intelektuālā īpašuma tiesību jomas sakārtošana (datu sniedzējiem jāpaliek to turētājiem, platformas pašas par sevi ir tirgi, regulatīvais ietvars platformām, pieeja infrastruktūrai), jaunās nodarbinātības formas, starptautiskā sadarbība, īpaši attiecībā uz digitālās ekonomikas aplikšanu ar nodokḷiem, datu analīze un procesu mērǐšana.

Covid-19 izraisītā krīze ir parādījusi, ka digitālo tehnolog̣iju izmantošana palīdz ierobežot negatīvo ietekmi uz uzņēmējdarbības modelıiem. Tāpēc ekonomikas digitalizācijas pakāpe lielā mērā noteiks ekonomikas noturību un atgūšanas spēju.

Darbaspēka pieejamībai un kvalitātei ir būtiska loma produktivitātes paaugstināšanā. Mainās izglîtības paradigma. Sabiedrībai jāpielāgojas, jo turpmāk jāmācās būs visas dzīves garumā. Jaunu kompetenču iegūšana un kvalifikācijas celšana būs būtiska cilvēka darba pieredzes sastāvdaḷa. Cilvēki, kuri nespēs regulāri papildināt un atjaunot zināšanas, riskē zaudēt konkurētspēju uzṇēmējdarbībā un darba tirgū, kā arī ienākumu līmeni. Vairumam profesiju jau tagad ir nepieciešamas jaunas zināšanas, tostarp tehnologiskās zināšanas. Īpaši to izjūt un nākotnē visvairāk izjutīs strādājošie zemākā un vidējā kompetenču līmeņa profesijās.

Progress neizstumj cilvēku no darba tirgus. Gluži pretēji - tas rada jaunas iespējas, jaunas profesijas. Cilvēks spēj strādāt "gudrāk", ieguldīt darbā zināšanas un prasmes un attiecīgi arī saņem lielāku algu. Taču jaunas tehnologijas prasa arī jaunas zināšanas. Pat šķietami vienkāršu darbu veikšanai vairs nepietiek tikai ar pabeigtu vidējo izglìtíbu.

2020. gada Pasaules Ekonomikas foruma pētijums atklāja, ka 50\% darba vietu pastāv risks, ka tās būtiski mainīsies vai novecos. ${ }^{25}$ Pēc Covid-19 krīzes tas kḷūst vairāk iespējams. Pateicoties visiem pandēmijas izraisītajiem pielāgojumiem darba vietā, daudziem rodas jautājums, kā pārkvalificēt pieejamo darbaspēku jauno digitālo tehnolog̣iju kontekstā.

Darba tirgus tendences un nākotnes perspektīvas ir padziḷināti analizētas Ekonomikas ministrijas informatīvajā ziṇojumā par darba tirgus vidēja un

25 World Economic Forum. (2020). The Future of Jobs Report. Pieejams: https://www.weforum.org/ reports/the-future-of-jobs-report-2020 
12. attēls. Prognozējamais darbaspēka pārpalikums/trūkums un absolventu skaits pa izglîtības posmiem un jomām (piedāvājuma un pieprasījuma starpība 2027. gadā, absolventu skaits 2019. gadā)

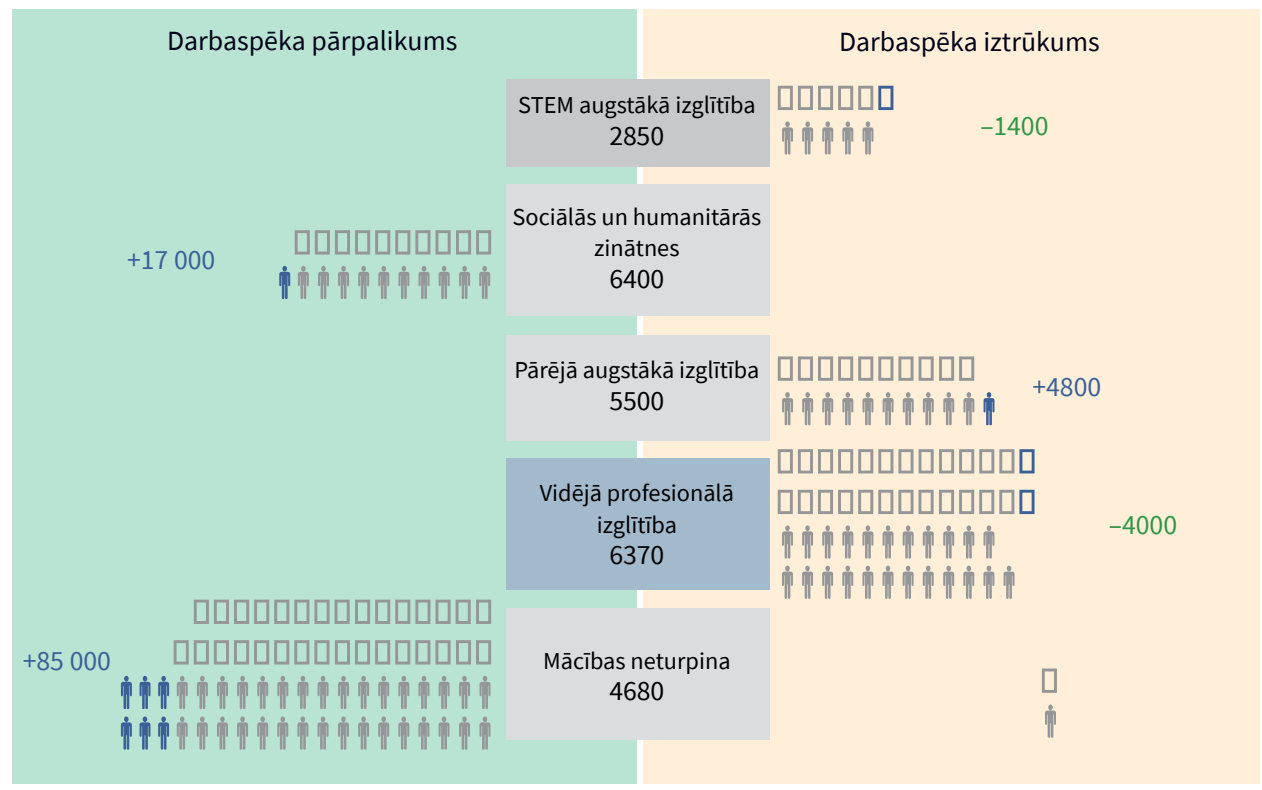

Avots: Ekonomikas ministrijas Informatīvais ziņojums par darba tirgus vidēja un ilgtermiṇa prognozēm, 2020.

ilgtermiṇa prognozēm. ${ }^{26}$ Galvenie Latvijas darba tirgus izaicinājumi vidējā termiṇā saistāmi ar darbaspēka novecošanos un darbaroku trūkumu. Darbaspēka novecošanās tendences visvairāk ietekmēs vidējās kvalifikācijas darbaspēka pieejamību, jo īpaši transporta pakalpojumos un uzglabāšanā, būvniecībā, apstrādes rūpniecībā, kā arī lauksaimniecībā un tirdzniecībā. Tāpat darbaspēka nepietiekamība var veidoties nozarēs, kurās sagaidāms nozīmīgs augstākās kvalifikācijas darbaspēka pieprasījuma pieaugums - profesionālos, zinātniskos un tehniskos pakalpojumos un informācijas un komunikācijas pakalpojumos, jo īpaši STEM jomās (12. attēls).

Lai nākotnē samazinātu iespējamās darba tirgus disproporcijas, problēmas ir jārisina kompleksi. Piemēram, ir grūti palielināt studējošo skaitu dabaszinātnēs un inženierzinātnēs, ja jau pamatizglītībā un vidējā izglìtībā skolēniem ir vājas zināšanas un maza interese par eksaktajiem mācību priekšmetiem. Tāpat jāṇem

26 Ekonomikas ministrija. (2020). Informatīvais ziṇojums par darba tirgus vidēja un ilgtermiņa prognozēm. Rīga. Pieejams: https://www.em.gov.lv/lv/ekonomikas_attistiba/darba_tirgus/videja_un_ilgtermina_darba_tirgus_prognozes/ 
vērā, ka iespējamie risinājumi augstākajā izglìtībā, vidējā, vidējā profesionālajā izglìtībā un pamatizglìîibā jūtamu ietekmi dos ilgtermiņā. Izmaiņas formālajā izglītỉbā atstāj relatīvi mazu ietekmi uz vidēja termiņa problēmām. ${ }^{27}$

Pārkvalifikācija un kvalifikācijas paaugstināšana ir svarīgi instrumenti, lai novērstu mūsdienu tehnologiju darbaspēka prasmju trūkumu. Kvalifikācijas celšana ietver jaunu prasmju apgūšanu vai darba ņēmēju jaunu prasmju mācī̌šnu, savukārt kvalifikācijas paaugstināšana ietver jaunu prasmju apgūšanu, lai kvalificètos citam darbam, vai māca darbiniekiem jaunas prasmes, lai palīdzētu viṇiem iegūt jaunu darbu tajā pašā uzṇēmumā vai citur.

Šobrīd Latvijā tikai neliela daļa pieaugušo iedzīvotāju piedalās mūžizglītības aktivitātēs. 2019. gadā mūžizglìtībā bija iesaistīi tikai 7,4\% iedzīvotāju 20-64 gadu vecumā. Tas ir viens no zemākajiem rādītājiem Eiropas Savienībā. Galvenie kavējošie faktori efektīvas mūžizglìtîbas sistēmas izveidē ir iedzīvotāju zemā interese, jo pamatā tiek pieprasīti kursi un programmas individuālo kompetenču celšanai un brīvā laika interesēm, nesaistot to ar iespēju palielināt savus ienākumus darba tirgū. Kavējošs faktors ir arī vāja reǵionālā mobilitāte. Nereti potenciāli zemais atalgojums nemotivē iesaistīties ilgākos apmācības kursos. Uzņēmumu aktīvāku iesaisti darbinieku mācībās ierobežo pastāvošais ekonomikas modelis, kurā dominē "zemo izmaksu" stratēgijas un neatmaksājas investēt darbinieku izglìīibā. Sistēmas efektīvu attīstību ierobežo arī mācību satura piedāvājuma un pieprasijjuma neatbilstîba, jo pieaugušo izglìtības tirgū nereti ir lēti, mazāk kvalitatīvi piedāvājumi. Savukārt publiskā sektora mācību iestādes ierobežo administrēšanas un finansēšanas mehānismi, kas pašlaik nav motivējoši.

Pieaugušo izglìtības sistēmas efektivitātei būs nozīmīga loma Covid-19 negatīvo seku mazināšanā un kopèjā tautsaimniecības produktivitātes līmeṇa paaugstināšanā. Îstermiņa galvenā prioritāte ir Covid-19 krīzes radītā bezdarba mazināšana, lai palīdzētu ātrāk atgūties no recesijas, lai cilvēki atkal atgrieztos darbā un ierobežotu ilgstoša bezdarba riskus. Jāveicina darbaspēka pāreja no nozarēm, kas piedzīvo apjomīgu kritumu un, visticamāk, ilgstoši neatgūs pirmskrīzes līmeni, uz nozarēm, kas turpina augt arī pandēmijas apstākḷ̆os.

Tautsaimniecībā pastāvīgi notiek lielākas vai mazākas strukturālās pārmaiņas. Lai sagatavotos un pielāgotos šìm izmaiņām, ir nepieciešams veikt apsteidzošus pārkārtojumus darba tirgū, kas ietver darba tirgus vidēja un ilgtermiņa prognozēšanu, dialogu starp iesaistìtajām pusēm un lēmuma pieņemšanu par izmaiṇām darbaspēka sagatavošanas struktūrā. Šādi labi strādājoša sistēma var

27 Ekonomikas ministrija. (2018). Informatīvais ziṇojums par darba tirgus vidēja un ilgtermiṇa prognozēm. Rìga, 79. lpp. 
novērst nākotnē darba tirgus disproporcijas un ir nozīmīgs elements darbaspēka piedāvājuma un pieprasījuma pielāgošanās procesa veicināšanā.

Lai arī Latvijā jau vairākus gadus tiek strādāts pie šādas sistēmas izveides, pārmaiṇas apsteidzošie pārkārtojumi Latvijas darba tirgū vēl joprojām ir nepilnīgi un nepietiekami mērḳtiecīgi, darba tirgus jautājumu risināšanai nav izveidots strukturēts un integrēts pārkārtojumu vadības modelis. Tāpat Latvijā ir nepietiekamas visaptverošas visu līmeņa diskusijas par darba tirgus nākotnes tendencēm un vajadzībām.

\section{Produktivitāti veicinošā politika un attīstības scenāriji}

Dažādos pētījumos norādīts, ka kopumā globālo ekonomiku sagaida būtiskas pārmaiṇas. Radīsies jaunas priekšrocības, veidosies jauni attīstības virzieni un jaunas produktu un pakalpojumu nišas. Turklāt Covid-19 krīze kalpo kā katalizators straujākām pārmaiṇām. Arī globālās tehnoloǵiju tendences un jaunās Eiropas Savienības politikas iniciatīvas ietekmēs tautsaimniecības attīstību nākotnē. Sagaidāmās struktūras pārmaiṇas ir cieši saistītas ar produktivitātes kāpināšanas aspektu, jo svarīgi ir sekmēt resursu pārdali par labu produktīvām jomām, tādējādi palielinot arī kopējo ekonomikas produktivitātes līmeni.

N̦emot vērā Covid-19 ietekmi, tehnoloğiju straujo attīstību un jaunās iniciatīvas klimata jomā, nepieciešams gudri ieguldīt publiskos līdzekḷus ekonomikas kapacitātes noturēšanā īstermiṇā un ekonomikas transformācijas pasākumiem vidējā un ilgtermiņā. Pēc pašreizējās informācijas 2021. gada sākumā, provizoriski Latvijai ir pieejami aptuveni 18 mljrd. EUR nākamajiem 7-8 gadiem. Finanses ietver gan Covid-19 krīzes pārvarēšanai pieejamos resursus, gan esošā ES fondu plānošanas perioda līdzekḷus, gan vidēja termiņa plānošanas dokumentos iezīmētos valsts budžeta ieguldỉjumus, kā arī ES daudzgadu budžeta paredzēto finansējumu (13. attēls).

Lai panāktu straujāku produktivitātes pieaugumu un nodrošinātu stabilu ekonomikas izaugsmi, vitāli svarīgi ir ne vien ilgtspējīgi ieguldīt pieejamos publiskos finanšu līdzekḷus, bet arī veicināt privāto investīciju apjoma pieaugumu, stimulējot kreditēšanas pieaugumu, kapitāla tirgus attīstību un finanšu instrumentu izmantošanu. 2005.-2007. gada periodā vidēji privātās investīcijas sasniedza 29,3\% no IKP, pēdējos gados privāto investīciju līmenis svārstās $16-17 \%$ apmērā no IKP. Salīdzinājumā ar 2005.-2007. gada periodu privāto investīciju plaisa ir vērtējama 2,4 mljrd. EUR apjomā, kas lielā mērā ietekmē arī lēnāku produktivitātes izaugsmi pēdējos gados. 


\section{3. attēls. Latvijas tautsaimniecības modernizācijai pieejamais indikatīvais publiskais finansējums 2020.-2027. gadam (milj. EUR)}

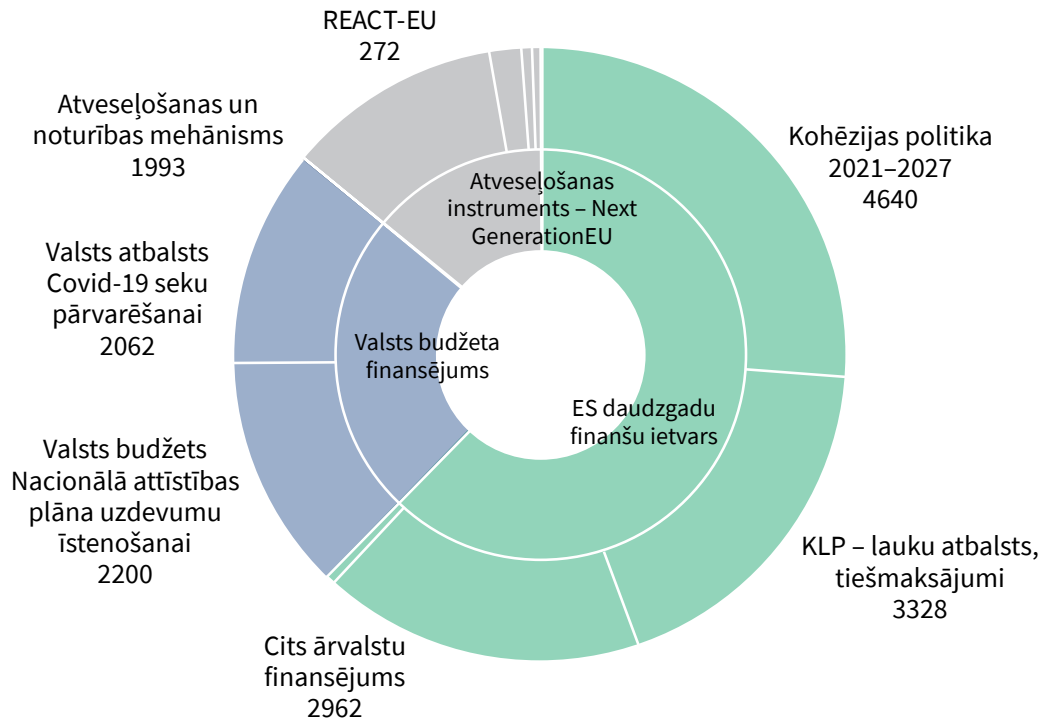

Avots: autoru aprēḳins, balstoties uz EK, FM un PKC datiem.

Lai novērtētu Latvijas tautsaimniecības attīstības perspektīvas post-Covid periodā, ir modelēta ${ }^{28}$ tautsaimniecības kopējā un ekonomikas pamatnozaru attīstība līdz 2030. gadam. Covid-19 pandēmijas radītie ierobežojumi negatīvi ietekmē ekonomiku, tomēr tautsaimniecības attīstības izaicinājumi vidējā termiṇā, kas jau ir noteikti politikas plānošanas dokumentos kā nepieciešamība palielināt Latvijas preču un pakalpojumu eksportu un produktivitāti, nemainās.

Latvijas attīstības modelēšanas procesā tika aplūkoti divi attīstības scenāriji - trenda un paātrinātas izaugsmes scenārijs, kā arī vērtēta katra attīstības scenārija ietekme uz produktivitātes dinamiku. Pamatpieṇēmumi par katru no scenārijiem ir sniegti 1. tabulā.

28 Tautsaimniecības attīstības prognožu izstrādei izmantots autoru izstrādāts un Latvijas ekonomikai pielāgots Hermin vidēja termiṇa modelis, kas ir balstīts uz tradicionālo keinsiānisko darbības mehānismu - izlaide ir atkarīga gan no iekšējā, gan ārējā pieprasījuma. Tomēr modelim piemīt arī neoklasiskās teorijas īpašîbas. Tā, piemēram, ražošanas apjomi apstrādes rūpniecības sektorā ir atkarīgi ne tikai no pieprasījuma, bet arī no cenu un izmaksu konkurētspējas. Turklāt pieprasijjums pēc ražošanas faktoriem tiek noteikts ar CES funkciju (Constant elasticity of substitution), kur kapitāla un darbaspēka attiecība ir atkarīga no relatīvām ražošanas faktoru izmaksām. 


\section{1. tabula. Latvijas attīstības scenāriju pamatpieṇēmumi}

\begin{tabular}{|c|c|c|}
\hline Faktors & $\begin{array}{l}\text { TRENDA SCENĀRIJS } \\
\text { Produktivitāte aug atbilstoši } \\
\text { iepriekšëjam trendam }\end{array}$ & $\begin{array}{c}\text { PAĀTRINĀJUMA SCENĀRIJS } \\
\text { leguldījumi un valsts atbalsts sekmē } \\
\text { pāreju uz augstāku produktivitātes līmeni }\end{array}$ \\
\hline ĀRĒJĀ VIDE & $\begin{array}{l}\text { Covid-19 izplatība saglabājas } \\
\text { vilnnveidīga līdz efektīvas vakcīnas } \\
\text { izstrādei. Situācija normalizējas } \\
\text { 2021. gada nogalē. }\end{array}$ & $\begin{array}{l}\text { Covid-19 izplatība saglabājas vil̦nveidīga } \\
\text { līdz efektīvas vakcīnas izstrādei. Situācija } \\
\text { normalizējas 2021. gada nogalē. }\end{array}$ \\
\hline \multirow{2}{*}{$\begin{array}{l}\text { COVID-19 } \\
\text { IETEKME }\end{array}$} & \multirow{2}{*}{$\begin{array}{l}\text { Smagāk skartās nozares atkopjas lēni. } \\
\text { Pirmskrīzes apjomu sasniegšana var } \\
\text { prasīt vairākus gadus. Ekonomikas } \\
\text { transformācijas process ir lēns. }\end{array}$} & $\begin{array}{l}\text { Uzņēmumi meklē risinājumus pārorientēt } \\
\text { darbību no vissmagāk skartām jomām uz } \\
\text { jaunām uzñēmējdarbības nišām. }\end{array}$ \\
\hline & & $\begin{array}{l}\text { Tirdzniecībā attīstās e-komercijas prakse. } \\
\text { Saglabājas elastīgas darba formas. }\end{array}$ \\
\hline \multirow[t]{2}{*}{$\begin{array}{l}\text { INVESTİCIJAS, } \\
\text { TEHNOLOG̦IJAS }\end{array}$} & \multirow[t]{2}{*}{$\begin{array}{l}\text { Investīijijas esošo biznesa modeḷu } \\
\text { saglabāšanā. }\end{array}$} & $\begin{array}{l}\text { Pieejamo finanšu līdzeklu ieguldījumi } \\
\text { produktivitātes plaisas mazināšanā } \\
\text { ar tehnoloğiski attīstītajām valstīm. } \\
\text { leguldījumi ne tikai tehnoloğiskās } \\
\text { novitātes, bet arī ražošanas procesu } \\
\text { vadības pilnveidošanā. }\end{array}$ \\
\hline & & $\begin{array}{l}\text { Privāto investīciju apjoms līdz 2027. gadam } \\
\text { pieaug līdz 25\% no IKP. }\end{array}$ \\
\hline \multirow{2}{*}{$\begin{array}{l}\text { INOVĀCIJA, } \\
\text { PÉTNIECIİBA }\end{array}$} & \multirow{2}{*}{$\begin{array}{l}\text { leguldījumi pētniecībā un attīstība } \\
\text { turpina pieaugt lēni. Latvija ilgstoši } \\
\text { saglabā vājāko pozīciju starp ES } \\
\text { dalībvalstīm. }\end{array}$} & $\begin{array}{l}\text { Būtiski palielinās finansējums pētniecībai } \\
\text { un attīstībai, 2027. gadā sasniedzot } \\
\text { 1,5\% no IKP. }\end{array}$ \\
\hline & & $\begin{array}{l}\text { Pieaug uzñēmumu pašu veikto pētījumu } \\
\text { izdevumu îpatsvars. }\end{array}$ \\
\hline \multirow[t]{2}{*}{ DIGITALIZĀCIJA } & \multirow{2}{*}{$\begin{array}{l}\text { Turpinās sāktās atsevišǩu uzñēmumu } \\
\text { iniciatīvas ( } 5 \mathrm{G} \text {, gēni, viedā pilsēta), } \\
\text { taču turpina pieaugt atšǩirības } \\
\text { starp uzñēmumiem, kas ir digitālo } \\
\text { tehnologiju līderi, un uzñēmumiem, } \\
\text { kas digitālos risinājumus izmanto kūtri. }\end{array}$} & $\begin{array}{l}\text { Atbilstoši katra uzñēmuma digitālā } \\
\text { brieduma pakāpei notiek nepārtraukts } \\
\text { digitālo tehnoloǵiju ieviešanas process. } \\
\text { Veidojas jauni produkti un tirgus nišas. }\end{array}$ \\
\hline & & $\begin{array}{l}\text { Papildu ieguldījumi uzṇēmējdarbības } \\
\text { digitalizācijā } 250 \text { milj. EUR apmērā līdz } \\
\text { 2027. gadam. }\end{array}$ \\
\hline ZAL̨AIS KURSS & $\begin{array}{l}\text { Vides prasību ievērošanai Latvija } \\
\text { importē zal̦ās tehnoloǵijas. }\end{array}$ & $\begin{array}{l}\text { Savlaicīga pārorientācija un sagatavošanās } \\
\text { pārmaiņām. Jaunu biznesa nišu meklēšana } \\
\text { zal̦o tehnoloğiju izstrādei un eksportam. }\end{array}$ \\
\hline \multirow{4}{*}{ CILVĒKKAPITĀLS } & \multirow{4}{*}{$\begin{array}{l}\text { Vidējā termiñā turpina pieaugt } \\
\text { darbaspēka piedāvājuma un } \\
\text { pieprasījuma neatbilstība. } \\
\text { Sabiedrības iesaiste pieaugušo izglìtībā } \\
\text { saglabājas 7-8\% līmenī. } \\
\text { Tirgū dominē salīdzinoši īsas mācības } \\
\text { vispārējo kompetenču paaugstināšanā. }\end{array}$} & $\begin{array}{l}\text { Papildus ik gadu } 150 \text { milj. EUR publisko un } \\
\text { privāto ieguldījumu prasmju pilnveidei. }\end{array}$ \\
\hline & & $\begin{array}{l}\text { Valsts subsidētas 6-9 mēnešus ilgas } \\
\text { mācību programmas darbaspēka } \\
\text { pārkvalificēšanai uz nozarēm ar lielāko } \\
\text { izaugsmes potenciālu. }\end{array}$ \\
\hline & & $\begin{array}{l}\text { Pieaugušo izglīīibas piedāvājums jauno } \\
\text { digitālo tehnoloğiju kontekstā visāmm } \\
\text { sabiedrības grupām, tādējādi mazinot } \\
\text { nevienlīdzības pieauguma riskus. }\end{array}$ \\
\hline & & $\begin{array}{l}\text { Darba devēju aktīva iesaiste esošo } \\
\text { darbinieku kompetenču paaugstināšanā, } \\
\text { kā arī jaunu prasmju kopu izveide, } \\
\text { lai cilvēki varētu kvalificēties jaunām } \\
\text { profesijām ekonomikas transformācijas un } \\
\text { robotizācijas apstākḷlos. }\end{array}$ \\
\hline
\end{tabular}




\section{4. attēls. Latvijas tautsaimniecības izaugsmes scenāriji}

(IKP salīdzināmās cenās, 2010. gads $=100$ )

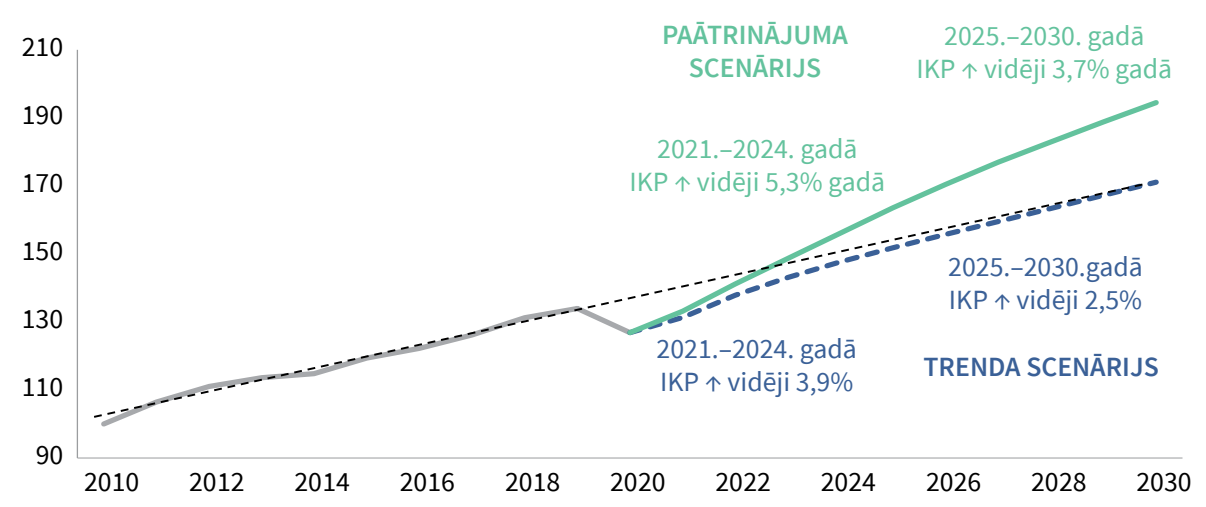

Trenda scenārijā, saglabājoties līdzšinējām tendencēm, tuvākajos gados (no 2021. līdz 2024. gadam) IKP izaugsme varētu sasniegt vidēji 3,9\% gadā, turpmākajos gados ekonomikas ikgadējie izaugsmes tempi kḷūs lēnāki un būs 2,5\% robežās. Šajā scenārijā pirms Covid-19 pandēmijas krīzes līmenis (2019. gads) tiek sasniegts 2022. gadā. Savukārt ekonomika pie pirmskrīzes izaugsmes trenda atgriežas tikai 2027. gadā.

Paātrinājuma scenārijā, kas paredz konkurētspējas priekšrocību balstî̌sanu uz tehnologiskiem faktoriem, ražošanas efektivitāti, inovācijām, kā arī uz spēju pielāgoties un izmantot globālo pārmaiṇu radītās iespējas, ekonomikas izaugsme laika periodā no 2021. lìdz 2024. gadam var sasniegt vidēji 5,3\% ik gadu, turpmākajos 10 gados vidēji 3,7\% ik gadu (14. attēls).

Kopumā aprēḳini parāda, ka jaunāko tehnologiju ieviešana, jaunu produktu un pakalpojumu attīstī̌sana, kā arī digitālo risinājumu plašāka izmantošana un procesu efektivitātes uzlabošana rada būtisku ietekmi uz straujāku nozaru un visas tautsaimniecības izaugsmi. Produktivitātei abos attīstības scenārijos ir lielākais devums izaugsmē. Tomēr nozīmīgs faktors straujākas izaugsmes nodrošināšanā ir arī darbaspēka pieejamības problēmas risinājumiem. Ieguldījumiem cilvēkkapitālā ir ḷoti liela nozīme. Kritiski svarīgi ir nodrošināt augošās un produktīvās nozares ar darbaspēku, kas nozīmē, ka ir jāpārskata līdzšinējās pieaugušo izglìtības programmas un jāveicina darbaspēka pārplūde no mazāk produktīviem sektoriem uz produktīvām nozarēm. 


\section{Secinājumi}

Produktivitātes dinamika Latvijā pēdējās desmitgadēs ir bijusi visai strauja un pārsniegusi ES vidējos pieauguma tempus. Tomēr, salīdzinot ar ES augsti attīstītajām valstīm, joprojām saglabājas būtiska Latvijas produktivitātes līmeņa atpalicība, kas ir skaidrojama galvenokārt ar zemo kopējo faktoru produktivitāti, būtiskām atškirīibām ražošanas resursu (cilvēku un kapitāla) kvalitātē. Covid-19 krīze ir padziḷinājusi ekonomiskos riskus.

Produktivitātes konverǵences dinamikas palēnināšanās liecina par "produktivitātes slazdu", kura pārvarēšanai ir nepieciešams paātrināt strukturālās reformas un būtiski uzlabot inovatīvos risinājumus.

Produktivitātes pieaugumam arvien vairāk būs jābalstās uz zinātnesietilpīgām darbībām, kuru īpatsvars ekonomikā šobrīd ir mazs. Latvijas vājākais punkts ir inovācijas, kam nepieciešami ieguldījumi pētniecībā un izstrādē, kā arī cilvēku zināšanu un prasmju pilnveidošanā. Jāuzlabo inovāciju sistēmas tiesiskais regulējums, valsts atbalsta sistēma intelektuālā īpašuma radīšanā, komercializācijā un praktiskā īstenošanā. Valstij jākoordinē izcilu inovatīvu produktu komercializācija, jāizstrādā ekonomiskais pamatojums un tiesiskais regulējums inovāciju iepirkumam. Latvijas sniegumam inovāciju jomā varētu nākt par labu aktīvāka lielāko valsts uzṇēmumu iesaistǐšanās, kuriem ir resursi un kuri varētu veikt būtiskus ieguldijumus.

Pilnīga digitalizācijas iespēju izmantošana ir būtiska, lai uzturētu produktivitāti un uzlabotu dzīves līmeni. Latvijā ir izveidojusies digitālā plaisa starp pilsētu un laukiem. Lielai daḷai Latvijas iedzīvotāju trūkst digitālo pamatprasmju. Digitālo tehnolog̣iju integrācija uzṇēmumos ir krietni zem ES vidējā līmeņa. Kopumā Latvijas sabiedrība nav pilnībā gatava ekonomikas digitālam izrāvienam. Galvenajiem politikas virzieniem jābūt digitālo prasmju palielināšanai sabiedrībai kopumā, specifiski orientējoties uz katru mērķa grupu, lai novērstu nevienlīdzības risku nākotnē.

Darbaspēka pieejamībai un kvalitātei ir būtiska loma produktivitātes paaugstināšanā. Lai sekmētu cilvēkkapitāla attīstību, Latvijā ir īstenotas vai sāktas vairākas reformas, kuru pozitīvo ietekmi uz kopējo produktivitātes līmeni var sagaidīt tikai vidējā vai ilgtermiṇā. Darbaspēka novecošanās tendences visvairāk ietekmēs vidējās kvalifikācijas darbaspēka pieejamību, jo īpaši transporta pakalpojumos un uzglabāšanā, būvniecībā, apstrādes rūpniecībā, kā arī lauksaimniecībā un tirdzniecībā. Tāpat darbaspēka nepietiekamība var veidoties nozarēs, kurās sagaidāms nozīmīgs augstākās kvalifikācijas darbaspēka pieprasījuma pieaugums - profesionālos, zinātniskos un tehniskos pakalpojumos un informācijas un komunikācijas pakalpojumos, jo īpaši STEM jomās. 
Redzot, ka nākotnē darba tirgū saasināsies darbaspēka nepietiekamības problēma, ir nepieciešams stiprināt pieaugušo izglītỉbas sistēmu, lai nodrošinātu darbaspēka pāreju no neproduktīvām jomām uz augošām nozarēm. Pieaugušo izglīiības sistēmas efektivitātei būs nozīmīga loma arī Covid-19 negatīvo seku mazināšanā un kopējā tautsaimniecības produktivitātes līmeṇa paaugstināšanā. Ieguldījumi cilvēkkapitālā ir nozīmīgs faktors straujākas izaugsmes nodrošināšanā.

N̦emot vērā Covid-19 ietekmi, tehnologiju straujo attīstību un jaunās iniciatīvas klimata jomā, nepieciešams gudri ieguldìt publiskos līdzekḷus ekonomikas kapacitātes noturēšanā īstermiṇā un ekonomikas transformācijas pasākumiem vidējā un ilgtermiṇā. Aprēḳini rāda, ka jaunāko tehnolog̣iju ieviešana, jaunu produktu un pakalpojumu attīstišana, kā arī digitālo risinājumu plašāka izmantošana un procesu efektivitātes uzlabošana rada būtisku ietekmi uz straujāku nozaru un visas tautsaimniecibas izaugsmi. 